SJ Quinney College of Law, University of Utah Utah Law Digital Commons

$10-2018$

\title{
Overstating America's Wrongful Conviction Rate? Reassessing the Conventional Wisdom About the Prevalence of Wrongful Convictions
}

Paul Cassell

S.J. Quinney College of Law, University of Utah, paul.cassell@law.utah.edu

Follow this and additional works at: https://dc.law.utah.edu/scholarship

Part of the Criminal Law Commons, and the Criminal Procedure Commons

Recommended Citation

Cassell, Paul G., 60 Ariz. L. Rev. 815 (2018)

This Article is brought to you for free and open access by the Utah Law Scholarship at Utah Law Digital Commons. It has been accepted for inclusion in Utah Law Faculty Scholarship by an authorized administrator of Utah Law Digital Commons. For more information, please contact valeri.craigle@law.utah.edu. 


\title{
OVERSTATING AMERICA's Wrongful CONVICTION RATE? REASSESSING THE CONVENTIONAL WiSDOM About the Prevalence of Wrongful CONVICTIONS
}

\author{
Paul G. Cassell*
}

A growing body of academic literature discusses the problem of wrongful convictions-i.e., convictions of factually innocent defendants for crimes they did not commit. But how often do such miscarriages of justice actually occur? Justice Scalia cited a figure of $0.027 \%$ as a possible error rate. But the conventional view in the literature is that, for violent crimes, the error rate is much higher-at least $1 \%$, and perhaps as high as $4 \%$ or even more.

This Article disputes that conventional wisdom. Based on a careful review of the available empirical literature, it is possible to assemble the component parts of a wrongful conviction rate calculation by looking at error rates at trial, the ratio of wrongful convictions obtained through trials versus plea bargains, and the percentage of cases resolved through pleas. Combining empirically based estimates for each of these three factors, a reasonable (and possibly overstated) calculation of the wrongful conviction rate appears, tentatively, to be somewhere in the range of $0.016 \%-0.062 \%$ - a range that comfortably embraces Justice Scalia's oftencriticized figure.

If this Article's tentative error-rate range is correct, it means that previous scholarship has significantly overstated the risk of wrongful conviction. Moreover, it is possible to compare the lifetime risk of being wrongfully convicted to the risk of being a victim of a violent crime. The relative risk ratio appears to be about 30,000 to 1. This decidedly skewed ratio suggests that reform measures for protecting the

* Ronald N. Boyce, Presidential Professor of Criminal Law and University Distinguished Professor of Law, S.J. Quinney College of Law at the University of Utah. Thanks to Ron Allen, Shima Baradaran Baughman, Tom Brunker, Patricia Cassell, Amos Guiora, Larry Laudan, Josh Marquis, Dan Medwed, Felicity Murphy, Leslie Risinger, Michael Risinger, George Thomas, Matt Tokson, Alec Walen, Marvin Zalman, and participants in colloquia at Seton Hall Law School and the S.J. Quinney College of Law. Maryann Dennis and Felicity Murphy provided excellent research assistance. All views expressed here are mine alone. This research was made possible in part through generous support from the Albert and Elaine Borchard Fund for Faculty Excellence. 
innocent may need to be cautiously assessed to ensure that they do not interfere with the important goal of prosecuting the guilty.

\section{TABLE OF CONTENTS}

I. Defining The “Wrongful Conviction” RAte AND its IMPORTANCE ..... 818

II. Calculating the Wrongful Conviction Rate by Combining EMPIRICALLY ESTIMATED COMPONENTS.................................................... 822

A. The Need for an Empirically Based Estimate ………................................ 822

B. The Component Parts of a Wrongful Conviction Rate .............................. 824

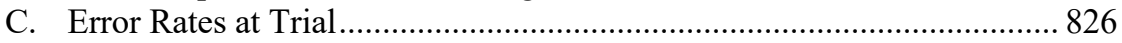

1. The Risinger Error-Rate Figure …………….................................. 826

2. The Typicality of the Error-Rate Samples.......................................... 833

3. Current Error Rates in Light of Advancing DNA and Other Improved Forensic Technologies ................................................... 837

D. The Ratio of Wrongful Convictions Through Trials and Guilty Pleas

E. Calculating the Wrongful Conviction Rate through Component Parts with Current Data.. 846

III. The Moral Culpability of Some of the Wrongfully Convicted .... 848

IV. Placing the Wrongful Conviction Rate in Context ........................... 851

A. The "Low" Risk of Wrongful Conviction................................................ 851

B. Ensuring that Innocence Reforms Do Not Block Prosecution of the Guilty

APPENDIX - ANALYSIS OF RISINGER'S WRONGFUL CONVICTION CASES

IN LIGHT OF CONTEMPORARY STANDARDS 857

\section{INTRODUCTION}

How often are innocent people wrongfully convicted in America's criminal justice system? This question has been aptly described as not only the most basic question about wrongful convictions but also the most important. ${ }^{1}$ For many reasons, we would like to have some quantitative assessment of this figure. For example, in considering a challenge to a state death penalty system, competing Supreme Court Justices debated the risk that an innocent person might be executed. ${ }^{2}$ In the course of that debate, Justice Scalia cited an error-rate estimate of $0.027 \%$ made by Clatsop County, Oregon District Attorney Josh Marquis. ${ }^{3}$ Justice Scalia went on to argue:

Like other human institutions, courts and juries are not perfect. One cannot have a system of criminal punishment without accepting the possibility that someone will be punished mistakenly. That is a truism, not a revelation. But with regard to

1. Samuel Gross, Convicting the Innocent, 4 ANN. REV. L. \& Soc. SCI. 173, 176 (2008).

2. Compare Kansas v. Marsh, 548 U.S. 163, 198 (2006) (Scalia, J., concurring), with id. at 209 (Souter, J., concurring).

3. Id. at 198 (Scalia, J., concurring) (citing Joshua Marquis, The Innocent and the Shammed, N.Y. TIMES, Jan. 26, 2006, at A23). 
the punishment of death in the current American system, that possibility has been reduced to an insignificant minimum. ${ }^{4}$

Professor Sam Gross (among others) has strongly critiqued Justice Scalia's tentative $0.027 \%$ calculation. ${ }^{5}$ But interestingly, while criticizing the figure, Gross also acknowledged that some sort of quantitative understanding of the error rate is important and, indeed, inherent in a burgeoning body of legal scholarship on wrongful convictions. Academics and others interested in the subject must have at least some implicit - and significant - error rate in mind, because otherwise they would be devoting their attention to a subject that does not really matter. ${ }^{6}$ After all, as Gross has concluded, "[i]f false convictions really were vanishingly rare$0.027 \%$ or some other absurd figure - they would not be much of a problem."

This Article is an effort to think seriously about the magnitude of the risk of wrongful conviction. To be sure, it will never be possible to precisely identify exactly how many people are wrongfully convicted each year. No government agency maintains an official ledger of every innocent person who was mistakenly convicted. ${ }^{8}$ But as the debate about specific error rates before the Supreme Court makes clear, the scale of the problem can have important public policy implications. It is, accordingly, quite useful to at least try to narrow the range of estimates. ${ }^{9}$

Interestingly, much of the recent innocence scholarship has simply despaired of any effort to quantify a wrongful conviction rate, calling that figure "unknown and frustratingly unknowable." 10 But, while staking out a position of unknowability, many of the same scholars have been willing to venture specific estimates of a false conviction rate-indeed, estimates well above $1 \%$. Professor Dan Simon's influential book, for example, summarizes the often-articulated conventional position that "[b]ased on exoneration data in two categories of capital homicide, the rate of error is estimated at about 3-4 percent, with a possible upper boundary of 5 percent. The rate of false convictions is most likely considerably higher."11

This Article challenges the seemingly developing conventional wisdom that the error rate in America's criminal justice system is 1\% or even higher. In fact, looking at the best available and current data, a conservative estimate of the error rate is somewhere close to the $0.027 \%$ posited by Justice Scalia. While one can debate whether such a small error rate makes wrongful convictions "vanishingly rare," this number is clearly considerably lower than the figure commonly cited by

4. Id. at 199 (Scalia, J., concurring).

5. Samuel R. Gross, Souter Passant, Scalia Rampant: Combat in the Marsh, 105

Mich. L. Rev. First Impressions 67, 69-70 (2006); see also Dan Simon, In DoubT: The Psychology of the Criminal Justice Process 226 n.12 (2012).

6. See Gross, supra note 1, at 175-76; see also Marvin Zalman, Qualitatively

Estimating the Incidence of Wrongful Convictions, 48 CRIM. L. Bull. 221, 230-31 (2012).

7. Gross, supra note 1, at 176.

8. An important private (but incomplete) effort in this direction is the National Registry of Exonerations, discussed at infra note 77 and accompanying text.

9. See Zalman, supra note 6, at 230-33.

10. SimON, supra note 5, at 4 (quoting Gross, supra note 5, at 69).

11. Id. 
innocence scholars and others who suggest a pressing need to adopt broad criminal justice reforms to reduce error rates even further.

This Article proceeds in several steps. It begins in Part I by defining the term "wrongful conviction rate," following the common approach in the innocence literature of looking at "wrong person" cases-i.e., factually innocent persons who have been convicted of crimes that they did not commit. The focus here will be wrongful convictions for crimes of violence, because those are, generally speaking, the most serious crimes.

Part II then turns to calculating an empirically based wrongful conviction rate. It is possible to simply qualitatively estimate a wrongful conviction rate. But without empirical grounding, such an estimate is of little real use. One empirically based approach can be described as a "component-parts approach." This approach breaks down the error rate into constituent pieces, starting with evidence of error rates at trial and other relevant figures. These figures can then be combined to produce an estimated general error rate for all convictions obtained through both trials and guilty pleas. Based on the available empirical evidence, the current general error rate for violent crime cases can be estimated at around $0.031 \%$, roughly the same as the figure suggested by Justice Scalia - and far below the figure commonly relied upon in innocence scholarship. Using this figure as a midpoint of a range of estimates produces an estimated wrongful conviction range of between $0.016 \%$ and $0.062 \%$.

Part III looks at the possible moral culpability of some of the wrongfully convicted for their plights. A significant risk factor for becoming a wrongfully convicted person is prior criminal history. This fact has been often overlooked in discussing wrongful convictions.

Part IV takes the wrongful conviction rate numbers derived through these various approaches and tries to place them into context. One way of doing this is to compare the lifetime risk of being wrongfully convicted for a violent crime with the lifetime risk of becoming a violent crime victim. This comparison suggests that a person is about 30,000 times more likely to fall victim to criminal violence than to become a wrongfully convicted prisoner. Part IV also explores the possible moral culpability of some of the wrongfully convicted for their plight, suggesting that this culpability may also need to be considered in assessing the scope of the wrongful conviction problem.

This Article concludes with some thoughts about what these numbers tell us about how America's criminal justice system is operating and how it might be improved in light of the data on wrongful convictions.

\section{DEFINING THE "WRONGFUL CONVICTION" RATE AND ITS IMPORTANCE}

Before attempting to quantify something, it is important to understand exactly what that something is. This Article attempts to provide a reasonable estimate of the "wrongful conviction" rate in the American criminal justice system. While the term "wrongful conviction" is found throughout a growing body of 
academic literature, ${ }^{12}$ at first blush, the term can seem imprecise. A conviction, after all, could be "wrongful" in a variety of ways. For example, a convicted defendant might have been initially selected for prosecution for inappropriate reasons. Or a convicted defendant may have introduced evidence at trial proving that, in the eyes of the law, he should not have been found guilty - perhaps for reasons of selfdefense, insanity, or other grounds for acquittal. Or it is even possible to define a "wrongful conviction" so broadly as to include simply cases in which a defendant can create reasonable doubt as to his guilt. ${ }^{13}$

Following the well-worn path of previous scholarship, this Article will focus more precisely not on "legal innocence" 14 but rather on "factual innocence" or "actual innocence"-i.e., "wrong man"15 or "wrong person" cases where someone is convicted for a crime he ${ }^{16}$ did not commit ${ }^{17}$ or for a crime that never actually happened. ${ }^{18}$ To be sure, situations where a defendant presents a legal claim (e.g., self-defense) that the jury mistakenly rejects are tragedies in their own right-

12. See, e.g., Wrongful Convictions And the DNA Revolution: Twenty-Five YEARS OF FreEING THE INNOCENT 138 (Daniel Medwed ed., 2017); WrongFul CONVICTION and CRiminal Justice Reform: Making Justice (Marvin Zalman \& Julia Carrano eds., 2014); Zalman, supra note 6, at 241 (estimating a "wrongful conviction" rate). The term "false conviction" is also sometimes used interchangeably. See, e.g., Samuel R. Gross, What We Think, What We Know and What We Think We Know About False Convictions, 14 OHIO ST. J. CRIM. L. 753 (2017); Roger Koppl \& Meghan Sacks, The Criminal Justice System Creates Incentives for False Convictions, 32 CRIM. JUST. ETHICs 126 (2013).

13. See Tony G. Poveda, Estimating Wrongful Convictions, 18 Just. Q. 689, 69597 (2001).

14. See Daniel S. Medwed, Innocentrism, 2008 U. ILL. L. REV. 1549, 1560; $c f$. Leah M. Litman, Legal Innocence and Federal Habeas, 104 VA. L. REV. 417, 436-62 (2018) (arguing that "legal innocence" cases are more akin to factual innocence cases than is generally recognized).

15. See, e.g., James M. Doyle, Learning from Error in American Criminal Justice, 100 J. CRIM. L. \& CRIMINOLOGY 109 (2010) (discussing "wrong man" convictions exposed by DNA).

16. Most of the wrongfully convicted are men. See Gross, supra note 12, at 756 (noting 91\% of the 1,900 individuals exonerated from January 1989 through October 2016 were men).

17. For similar approaches using factual innocence see, for example, Paul G. Cassell, The Guilty and the "Innocent": An Examination of Alleged Cases of Wrongful Conviction from False Confessions, 22 HARV. J.L. \& PUB. POL'y 523, 535 (1999); Zalman, supra note 6, at 246 (exploring "wrongful conviction" defined to mean "factual innocence and not... procedurally defective convictions"); see also Michael Radelet, How DNA Has Changed Contemporary Death Penalty Debates (discussing conceptual issues surrounding innocence), in Wrongful Convictions AND the DNA REVOlution, supra note 12, at 138; Joshua Marquis, The Myth of Innocence, 95 J. CRIM. L. \& CRIMINOLOGY 501, 508-09 (2005); Keith A. Findley, Defining Innocence, 74 Alb. L. REV. 1157 (2011); cf. Charles D. Weisselberg, Against Innocence, in The Integrity of Criminal Process: From Theory INTO PRACTICE 349 (Jill Hunter et al. eds., 2016) (contesting factual innocence standard).

18. See generally Jessica S. Henry, Smoke but No Fire: When Innocent People Are Wrongly Convicted of Crimes that Never Happened, 55 AM. CRIM. L. REV. 665 (2018). 
and "wrongful convictions" in some general, moral sense. ${ }^{19}$ But these kinds of wrongful convictions present different kinds of issues than this Article discusses.

Of course, determining exactly when such a wrong person miscarriage of justice has occurred can be the subject of debate. It is very easy for criminal justice critics to allege that an "innocent" person has been convicted even when the facts strongly suggest otherwise. ${ }^{20}$ But as DNA and other exonerations vividly document, clearly at least some cases of wrong person convictions have occurred. The focus of this Article is how often such wrongful convictions occur.

Before turning to quantification issues, it is important to recognize that a grave and serious injustice occurs whenever the criminal justice system wrongfully convicts people for crimes they did not commit. The harms extending from such convictions can be manifold and long-lasting. ${ }^{21}$ The most obvious harm is (for serious crimes, at least) a term of imprisonment - a term that can be substantial. Related to this consequence are financial, reputational, and other injuries that follow a wrongful conviction. ${ }^{22}$ And crime victims should not be forgotten. In cases of wrongful conviction, they will be traumatized when they learn "that the criminal who had attacked them had not been caught and punished after all, and that they themselves may have played a role in destroying the life of an innocent person." 23

Considering the serious repercussions of wrongful convictions, recent wrongful conviction scholarship has often focused on identifying the underlying causes of such miscarriages. ${ }^{24}$ The laudable goal of these efforts is to learn why the criminal justice system malfunctions, with an eye to correcting an individual cause (or, as is often the case, the compounding causes ${ }^{25}$ ) of wrongful convictions.

This Article maintains a slightly different focus. It tries to come to grips with the magnitude of the wrongful conviction problem. As with other serious social problems, the scope of the issue can have substantial implications, such as

19. See generally Findley, supra note 17, at 1163.

20. See Stephen J. Markman \& Paul G. Cassell, Protecting the Innocent: A Response to the Bedau-Radelet Study, 41 StAN. L. REV. 121 (1988) (responding to dubious claims that 23 "innocent" people have been wrongfully executed); Cassell, supra note 17 (responding to dubious claims that 29 "innocent" people were wrongfully convicted due to false confessions).

21. See Gross, supra note 12, at 756 ("[W]ith few exceptions every story [of false conviction] is a heartbreaking tragedy.").

22. See Robert J. Norris, Exoneree Compensation: Current Policies and Future Outlook, in Wrongful CONVICTION AND CRIMINAL JUSTICE REFORM, supra note 12, at 289.

23. Gross, supra note 12, at 755; see also Sion Jenkins, Families at War? Relationships Between "Survivors" of Wrongful Conviction and "Survivors" of Serious Crime, 20 Int'L Rev. Victimology 243 (2014).

24. See, e.g., Brandon L. Garrett, Convicting the Innocent Redux (collecting causes of wrongful convictions), in WRONGFUl CONVICTIONS AND THE DNA REVOLUTION, supra note 12 at $40,43-53$.

25. Julia Carrano \& Marvin Zalman, An Introduction to Innocence Reform ("[M] ost often wrongful convictions are attributable to several errors or instances of misconduct operating in concert."), in WRONGFUl CONVICTION AND CRIMINAL JUSTICE REFORM: MAKING JUSTICE, supra note 12, at 11, 15 (2014). 
determining the priority of resources to address the issue or the need for structural or other reforms. As Professors Carrano and Zalman have wisely explained:

The number of false convictions occurring each year is important; if minuscule when compared to total criminal convictions, it will be a minor justice problem in comparison to other concerns that should take precedence. If, however, miscarriages of justice are occurring at epidemic rather than episodic rates, wrongful conviction emerges as a major policy concern. ${ }^{26}$

Not all innocence scholars agree that the size of the problem matters. Professors Richard Leo and Jon Gould, for example, have argued that "it is not necessary to know the incidence or prevalence of a phenomenon to study it empirically or scientifically. Virtually every aspect of the study of American crime and criminal justice contains some incomplete or missing information." ${ }^{27}$ But while it is true that we can certainly study the wrongful conviction problem without knowing its prevalence, the problem's size presents tremendous public policy implications. For example, one of the country's leading innocence scholars, Professor Samuel Gross, concluded that if false convictions "really were vanishingly rare $-0.027 \%$ or some other absurd figure" - then we should conclude that they are not "much of a problem." 28 Presumably, it is because innocence scholars believe that wrongful convictions are a serious problem that they devote their time to studying the issue.

Indeed, while Professors Leo and Gould initially argued that the frequency of the wrongful convictions was "unknown and unknowable," 29 in a later article they acknowledge that existing research has "greatly narrowed the range." range that they identify runs from somewhere just above nonexistent to around 3\% to $5 \%$ of all convictions. ${ }^{31}$ As a practical matter, that is almost no range at all because most observers asked to estimate the size of the wrongful conviction problem would put it somewhere between $0.0001 \%$ and around $5 \% .{ }^{32}$

What Leo and Gould - and apparently many other innocence scholarsappear to implicitly assume is that the frequency of wrongful convictions tends toward the higher end of this range of possibilities-i.e., $1 \%$ or even more of all convictions. For example, summarizing the state of the innocence literature in 2017, Professor Gross concluded that the wrongful conviction rate for violent felonies "is somewhere in the range from one to several percent." ${ }^{33}$ Dan Simon recounts a working figure of "about 3-4 percent, with a possible upper boundary of 5

\footnotetext{
26. Id. at 13 (citation omitted).

27. Richard A. Leo \& Jon B. Gould, Studying Wrongful Convictions: Learning from Social Science, 7 ОHIо ST. J. CRIM. L. 7, 29 (2009).

28. Gross, supra note 1, at 176.

29. Leo \& Gould, supra note 27, at 29.

30. Jon B. Gould \& Richard A. Leo, One Hundred Years Later: Wrongful Convictions After a Century of Research, 100 J. CRIM. L. \& CRIMINOLOGY 825, 832 (2010).

31. Id.

32. See Marvin Zalman et al., Officials' Estimates of the Incidence of 'Actual Innocence' Convictions, 25 Just. Q. 72 (2008).

33. Gross, supra note 12, at 785.
} 
percent"-maybe something even higher. ${ }^{34}$ Figures in this range appear to be the emerging conventional wisdom about the magnitude of the wrongful conviction problem. $^{35}$

If the number of wrongful convictions was that high, the problem would truly be at epidemic levels. A $3 \%$ or $4 \%$ wrongful conviction rate would mean more than 10,000 innocent people are sent to prison every year. ${ }^{36}$ This would be a public policy problem of truly staggering proportions.

So let's turn to the numbers - how often are factually innocent people wrongfully convicted in America's modern criminal justice system?

\section{Calculating the Wrongful Conviction Rate by COMBINING EMPIRICALLY ESTIMATED COMPONENTS}

This Part takes up the challenge of trying to determine the "unknown and frustratingly unknowable" figure of the frequency of wrongful convictions. ${ }^{37}$ This Part begins by explaining why empirically based estimates should be preferred over qualitative assessments of the error rate. It then turns to one possible way of deriving a wrongful conviction rate: disaggregating the rate into component parts and then trying to assemble empirically based estimates for each of these parts. Based on the best estimates currently available, this Part concludes that for serious violent crimes, the error rate can be conservatively estimated to about .00031 or $0.031 \%$ or 3.1 out of 10,000 convictions - a figure considerably lower than other innocence scholars have suggested.

\section{A. The Need for an Empirically Based Estimate}

In attempting to quantify the size of the wrongful conviction problem, a researcher immediately runs into multiple difficulties. We know that wrongful

34. SIMON, supra note 5, at 4.

35. See, e.g., Brandon L. Garrett, Convicting the Innocent: Where Criminal Prosecutions Go Wrong 264 (2011) (criticizing Justice Scalia's 0.027\% error rate and suggesting that the true rate is likely more than 100 times higher, i.e., more than 2.7\%); Larry Laudan, The LaW's Flaws: Rethinking Trials and ERrors? 54 (2016) (reviewing exoneration studies and concluding that $3.25 \%$ is the mean estimate of a wrongful conviction rate); Findley, supra note 17, at 1169 (criticizing Justice Scalia's 0.027\% error rate and arguing " $[\mathrm{m}]$ ore serious analyses of the scope of the problem of wrongful convictions paint a very different picture"); Keith A. Findley, Toward a New Paradigm of Criminal Justice: How the Innocence Movement Merges Crime Control and Due Process, 41 Tex. TECH L. REV. 133, $142 \mathrm{n} .71$ (2008) (noting the 3.3\% to 5.0\% rate for capital rape murder calculated by Michael Risinger and calling it the "most empirically sound" effort to develop a wrongful conviction rate); Roger Koppl, Comment on Laudan, 48 Seton Hall L. Rev. 1255, 1256 (2018) (arguing 3\% wrongful conviction figure may be "too low"); see also Carrano \& Zalman, supra note 25 , at 14 (citing a $7.8 \%$ error rate in sexual assault cases and concluding it provides strong evidence "that wrongful convictions are widespread and numerous-more epidemic than episodic"); Lara Bazelon, For Shame: The Public Humiliation of Prosecutors by Judges to Correct Wrongful Convictions, 29 Geo. J. LegaL EтHICs 305, 330 (2016) (reviewing cases of exoneration and reaching the "inescapable conclusion" that "wrongful convictions are not isolated instances but a national epidemic").

36. See Zalman, supra note 6, at 225.

37. See, e.g., Simon, supra note 5, at 4. 
convictions occur, but no authoritative tabulation exists. Of course, if we knew that a person charged with a crime was innocent, we would not convict that person to begin with. It is only later —often years later-when a person is exonerated through DNA or other means that a wrongful conviction is revealed. But looking at these discovered exonerations can be problematic because they can be "uncommon, unpredictable, and unrepresentative of wrongful convictions in general." 38

One way to approach estimating the size of the error rate would be to ask knowledgeable people what they believe that error rate is. A recent summary of such approaches is contained in Professor Zalman's informative 2012 article, in which he attempted to collect all such estimates and then made his own estimate. ${ }^{39}$ After surveying the existing empirical literature on such estimated error rates, Zalman defended the proposition that a reasonable estimate of the wrongful conviction rate is $0.5 \%-1.0 \%$ for all felony offenses. He further argued that there was "clear and convincing" evidence and reason against any higher error rate. ${ }^{40}$

Zalman characterized his approach as a "qualitative" estimate." ${ }^{41}$ But while his approach is intriguing, it ultimately rests on little more than his own subjective sense of what the right figure is in this area. The approach has drawn fire from numerous observers, as Zalman himself acknowledges. ${ }^{42}$ For example, Judge Hoffman called it "a deeply flawed method," 43 Professors Gross and O'Brien viewed it as "just collective guess work," 44 and Professors Gould and Leo concluded it lacked any connection to the "underlying error rate in the real world of criminal justice." ${ }^{45}$

These criticisms have merit. It is one thing to ask experienced observers for an estimate when they have, in fact, observed something. It is quite another to ask them for estimates of something that they know may be occurring but do not have any real way of detecting. Perhaps such estimates can be used to provide a general order-of-magnitude calculation as to the size of problem. ${ }^{46}$ But while Zalman has labored long and hard to collect information about such estimates - and while he is a leading scholar in this area - at the end of the day, his subjective views on what is the right figure carry little weight to someone who takes a different point of view. For example, to my mind, even a $0.5 \%$ overall error rate would be very

38. Samuel R. Gross \& Barbara O'Brien, Frequency and Predictors of False Conviction: Why We Know So Little, and New Data on Capital Cases, 5 J. EMPIRICAL Legal STUD. 927, 929 (2008).

39. Zalman, supra note 6 , at 233-67.

40. Id. at 278 .

41. Id. at 222 .

42. Id. at 229 .

43. Morris B. Hoffman, The Myth of Factual Innocence, 82 CHI.-Kent L. REV. 663, 668 n.23 (2007).

44. Gross \& O'Brien, supra note 38, at 930.

45. Gould \& Leo, supra note 30, at 933-34 n.44.

46. Cf. Paul G. Cassell, Protecting the Innocent from False Confessions and Lost Confessions - and from Miranda, 88 J. CRIM. L. \& CRIMINOLOGY 497, 514 (1998) (relying on estimated error rates to create an upper boundary for the "false confession" problem, but cautioning that such an approach is not "empirically well founded"). 
much an upper bound of possible wrongful conviction rates, ${ }^{47}$ while others would find his $1 \%$ ceiling too low. But the decisive point remains that, without some realworld grounding, it is hard to determine whether any estimated number is too high, too low, or about right. To do better, some grounding in real-world data is needed.

\section{B. The Component Parts of a Wrongful Conviction Rate}

Various scholars have previously tried to assess the scope of the wrongful conviction problem. Indeed, nearly 20 years ago, I made a brief foray into the subject. ${ }^{48}$ The difficulty, of course, is that wrongful convictions are not easy to count. Despite the difficulty, however, we need not despair of any effort to attempt to assess the scope of the wrongful conviction problem. What may be required is simply to break the problem into various pieces of more manageable size.

One of the most helpful recent discussions along these lines came from Professors Ron Allen and Larry Laudan, who made a serious attempt to provide a methodology for quantifying a system-wide rate of wrongful convictions. ${ }^{49}$ Allen and Laudan separate the overall wrongful conviction rate into three component parts: the wrongful conviction rate at trial; the proportion of cases resolved by trial versus plea; and the ratio of wrongful convictions resulting from trial versus plea. ${ }^{50}$ When these three parts are multiplied together, the result is an estimated wrongful conviction rate for guilty-plea cases:

trial error rate

$\mathrm{x}$

ratio of wrongful convictions in guilty pleas versus trial

$\mathrm{X}$

overall ratio of trials to pleas

$=$

wrongful conviction rate in guilty-plea cases

47. Zalman appears to base his estimate, at least in part, on trial error rates. See Zalman, supra note 6, at 241-47. But the well-known fact is that the vast majority of criminal cases in America are resolved by guilty pleas. And it seems to be generally agreed in the innocence scholarship that defendants who are factually innocent are less likely to plead guilty than are those who are legally innocent. See infra notes 177-89 and accompanying text. Zalman apparently agrees that an adjustment needs to be made for the fact that error rates in guilty pleas are likely to be much lower, see Zalman, supra note 6, at 260-61, but he does not specifically explain how this fact is taken into account by his overall qualitative calculation.

48. Cassell, supra note 46, at 508-14 (discussing wrongful conviction figures in the context of false confessions).

49. See Ronald J. Allen \& Larry Laudan, Deadly Dilemmas, 41 Tex. Tech L. Rev. 65 (2008). For further developments of the argument, see, for example, Larry Laudan \& Ronald J. Allen, Deadly Dilemmas II: Bail and Crime, 85 ChI.-Kent L. Rev. 23 (2010); Ronald J. Allen \& Larry Laudan, Deadly Dilemmas III: Some Kind Words for Preventive Detention, 101 J. CRIM. L. \& CRIMINOLOGY 781 (2011); LAUDAN, supra note 35; Larry Laudan, Different Strokes for Different Folks: Fixing the Error Pattern in Criminal Prosecutions by "Empiricizing" the Rules of Criminal Law and Taking False Acquittals and Serial Offenders Seriously, 48 Seton Hall L. Rev. 1243 (2018).

50. $\quad$ Allen \& Laudan, Deadly Dilemmas, supra note 49, at 71. 
And with a conviction rate available for guilty-plea cases, a straightforward weighted average for all cases (both guilty-plea cases and trial cases) produces an overall wrongful conviction rate. ${ }^{51}$

The reason for this disaggregation is that some empirically based estimates are available for each of the three component parts. Perhaps the most important (and controversial) piece is the initial component-the wrongful conviction rate at trial. In making their calculations, Professors Allen and Laudan simply assumed a 5\% wrongful trial conviction, drawing upon Professor Risinger's important article on the subject. ${ }^{52}$ As discussed in the following Section, Professor Risinger collected a sample of cases-specifically, capital cases in which DNA exonerations had occurred; working backward from those exonerations, Risinger came up with a 3.3\% trial error rate and suggested that a likely maximum rate would be $5 \% .{ }^{53} \mathrm{~A}$ similar estimate has been made by Professor Samuel Gross, who estimated that the risk of wrongful conviction for all violent felonies (presumably at trial) is in the range of "one to several percent." 54

Allen and Laudan then argue, quite plausibly, that the percentage of wrongful convictions will be lower in cases where a defendant has decided to plead guilty rather than go to trial. ${ }^{55}$ Presumably, most people pleading guilty are, in fact, guilty. ${ }^{56}$ However, wrongful conviction research has established that, in some unusual cases, innocent people enter guilty pleas. ${ }^{57}$ To derive a specific figure for the wrongful conviction rate in cases involving plea bargains, Allen and Laudan rely on Professor Brandon Garrett's study of a collection of wrongful conviction cases in which only $4.5 \%$ were guilty pleas. ${ }^{58}$ Allen and Laudan then apply this figure to derive a weighted average of wrongful convictions for all cases, both those resolved through trial and those resolved through plea. ${ }^{59}$ Given that many more cases are resolved through plea bargaining than through trial, Allen and Laudan ultimately calculate an estimated error rate in the American criminal justice system of $0.84 \%$, or 8.4 out of 1000 convictions. ${ }^{60}$

51. While the Allen and Laudan approach was published a decade ago, to my knowledge no one has challenged the formula that they provide for deriving a number.

52. Allen \& Laudan, Deadly Dilemmas, supra note 49, at 71 (citing D. Michael Risinger, Innocents Convicted: An Empirically Justified Factual Wrongful Conviction Rate, 97 J. CRim. L. \& CRIMINology 761, 761 (2007)).

53. D. Michael Risinger, Innocents Convicted: An Empirically Justified Factual Wrongful Conviction Rate, 97 J. CRIM. L. \& CRIMINOLOGY 761, 780 (2007)

54. Gross, supra note 12, at, 785; see also Samuel R. Gross et al., Exonerations in the United States 1989 Through 2003, 95 J. CRIM. L. \& CRIMINOlOGY 523, 532 (2005).

55. Allen \& Lauden, Deadly Dilemmas, supra note 49, at 70-71.

56. Cf. Hoffman, supra note 43, at 672-73 (concluding that wrongful conviction via guilty plea is likely rare, but acknowledging pressures that modern plea bargaining practices place on defendants).

57. Brandon L. Garrett, Judging Innocence, 108 Colum. L. Rev. 55, 74 (2008)

58. Allen \& Laudan, Deadly Dilemmas, supra note 49, at 71 (discussing Garrett, supra note 57 , at 74$)$.

59. Id.

60. Id. at 71 (.05 trial error rate $\mathrm{x} 9 / 191$ ratio of wrongful convictions through plea compared to through trial $\times 16 / 84$ ratio of the number of trials convictions to the number of guilty pleas $=.00045$ ). 
Professor Risinger wrote a lengthy and interesting critique of the Allen and Laudan calculation. ${ }^{61}$ While Risinger makes many interesting points, the focus here will be on his argument that the Allen and Laudan error rate is understated. ${ }^{62}$ In fact, a careful assessment of the best-available data suggests that Allen and Laudan have overstated the rate. The following Sections use the component-parts methodology to calculate a risk of wrongful conviction for all violent crimes (conventionally defined by the FBI and other law enforcement agencies as murder, rape, robbery, and aggravated assault).

\section{Error Rates at Trial}

Consider first the wrongful conviction rate at trial. As the starting point for an error-rate calculation, this figure is perhaps the most important component part. And given that this figure measures the "black hole" of system malfunctions, it is difficult to determine. However, plausible approaches exist for tentatively developing an estimate.

\section{The Risinger Error-Rate Figure}

The $3.3 \%$ Risinger error-rate figure is useful to examine because it is one of the most widely cited in the wrongful conviction literature. ${ }^{63}$ Derived from a sample of capital rape-murder trials in the 1980s, it is one of the higher figures available in the empirical literature. ${ }^{64}$ The Risinger figure is also useful to examine

61. See D. Michael Risinger, Tragic Consequences of Deadly Dilemmas: A Response to Allen and Laudan, 40 Seton Hall L. Rev. 991 (2010).

62. Id. at 995-97, 1016.

63. See, e.g., Zalman, supra note 6, at 241 (identifying the Risinger figure as "the most robust death sentence wrongful conviction rate estimate"); see also Glossip v. Gross, 135 S. Ct. 2726, 2758 (2015) (Breyer \& Ginsburg, JJ, dissenting) (citing the 3.3\% error-rate figure).

64. It is not the highest error-rate estimate. That distinction appears to belong to a study done by the Urban Institute, which recently calculated an error rate of $11.6 \%$ in certain rape cases, up from an error rate of $7.8 \%$ that it had calculated in an earlier iteration of the same study. See Kelly Walsh et al., Estimating the Prevalence of Wrongful CONVICTION 1 (2017), https://www.ncjrs.gov/pdffiles1/nij/grants/251115.pdf; see also JOHN Roman et Al., Post-Conviction DNA Testing AND Wrongful Conviction 7 (2012), https://www.urban.org/sites/default/files/publication/25506/412589-Post-Conviction-DNATesting-and-Wrongful-Conviction.PDF.

The study used a retrospective analysis of retained physical-evidence files maintained by the Virginia Department of Forensic Science (DFS) from sexual assault and homicide cases dating from 1973 to 1987 . ROMAN ET AL., supra, at 4. It is worth considering how the data for the study was captured. The authors learned that a forensic serologist in Virginia, Jane Burton, had retained clippings of physical evidence in hundreds of her files apparently to use while testifying before the jury. $I d$. This physical evidence was retained after testing, while the underlying crime scene evidence was then returned to the originating jurisdiction. Id. Several decades later, the study's authors examined Burton's files to collect their data. $I d$.

This approach introduces four possible sources of bias. First, it seems likely that physical evidence was sent to Burton only when some sort of contested serological determination was required. Second, a question arises as to whether Burton would have made a clipping in all cases - or just one in which a dispute, and thus jury testimony, could be anticipated. Third, a question also arises as to whether she retained all of her files or just some 
because, unlike some other studies, there can be little doubt about the innocence of the people included in the study ${ }^{65}$ The exonerations are all based on publicly

of her files. For example, it is possible that she may not have retained files in cases where a defendant had readily admitted guilt or an originating jurisdiction advised that no jury trial was likely. Fourth, and related to this point, the study notes that the "vast majority" of physical evidence was tested by Burton, $i d$. at $14 \mathrm{n} .18$, but some (unidentified) proportion was tested by "serologists she had trained." Id. at 12 n.17. These samples are clearly subject to the problem of selection bias, because it seems clear that they were not a random sample of the cases analyzed by the trained serologists, but presumably were a small fraction of the cases they had handled. It seems reasonable to think that the files retained decades later would have been the most disputed or contentious cases, as the serologists might have been wondering about appeals and possible retrials.

In the latest version of the study, the authors have simply added in an additional five cases of exonerations, explaining (somewhat cryptically) that this was done "to ensure inclusion of exonerations that were a part of the set of convictions this study focuses on but did not have an available DFS file in [the initial study]." WALSH ET AL., supra, at $6 \mathrm{n}$.2. But because the convictions that the study focuses on, at least as originally described, were convictions involving a DFS file maintained by Burton, it is hard to understand the justification for simply adding in these additional exonerations. Given the small number of cases (29) from which the conclusions of the study are generated, see WALSH ET AL., supra, at 10 , all these questions raise concerns about the generalizability of the study's findings.

One other unfortunate limitation of the study is that it describes almost all of the "exoneration" cases pseudonymously. The study included two cases of acknowledged wrongful conviction, but as to the others it is impossible to evaluate the author's characterization of likely "exoneration"- or to see whether the governor (who had requested the reanalysis, Roman, supra, at 12) ultimately agreed with the characterization. This has to be regarded as a serious problem with the study, given the debate that swirls around what counts as sufficient proof of innocence to constitute an exoneration and concern that some studies have used inappropriately lax standards for making that determination. See supra note 20. In an effort to evaluate the reliability of the exoneration determinations, I requested identifiers from the study's authors. Unfortunately, they were precluded from releasing the names by their own internal policies and their data agreement with the National Institute of Justice. Email from Kelly Walsh to author (Jan. 10, 2018) (on file with author).

The facts just discussed suggest that the Urban Institute's number may overstate a wrongful conviction rate. It is worth noting, however, that as a measure of trial errors, the study may understate the rate of wrongful convictions, because it apparently included both trial cases and guilty-plea cases. Roman, supra, at 2.

65. While endorsing the reliability of the Risinger figure, Koppl and Sacks have estimated a wrongful conviction figure that rests on nothing more than situations where juries reached differing outcomes on the same facts in $12.5 \%$ of criminal case studies. See Koppl \& Sacks, supra note 12, at 131 . They note that in all the cases of disagreement, the defendant could have been guilty but conclude that "the opposite possibility seems no less possible." Id. But before a case can go to trial, a finding of "probable cause" must be made by the courts, see City of Riverside v. McLaughlin, 500 U.S 44 (1991), and a prosecutor must have determined that the admissible evidence provides a reasonable likelihood of proving guilt beyond a reasonable doubt, see Criminal Justice StANDARdS OF THE ProseCUTION FUNCTION $\quad \S \quad 3-4.3 \quad$ (AM. $\quad$ BAR $\quad$ Ass'N https://www.americanbar.org/groups/criminal_justice/standards/ProsecutionFunctionFourth Edition/. Accordingly, whenever a defendant is simply found not guilty beyond a reasonable doubt, all we say without any additional information is that it is much more likely that the defendant was, in fact, factually guilty rather than factually innocent. 
available DNA results, not softer measures of innocence ${ }^{66}$ or pseudonymous determinations of "innocence" that cannot be verified. ${ }^{67}$

It is important to note that Risinger's conclusions ultimately rest on a very small number of wrongful convictions - a total of only $11 .{ }^{68}$ It can be argued that reaching broad conclusions about the nation's criminal justice system from such a small sample builds on a limited foundation. ${ }^{69}$ But even more important, relying on Risinger's sample from capital rape-murder cases as an estimate of wrongful convictions for other cases - such as the general category of violent crime cases this Article focuses on - almost certainly produces a result that is too high. Indeed, Risinger himself cautioned about broad extrapolations, warning (quite properly) that the criminal justice system is "substructured," with different error rates for different kinds of crimes. ${ }^{70}$

To reach a more generally applicable error-rate figure, we can start with the fact that Risinger himself concluded that, within his sample, a 5\% error rate was a "fairly generous likely maximum," expanded from the $3.3 \%$ wrongful convictions figure actually demonstrated through DNA. ${ }^{71}$ If we want an empirically grounded rate, we might reasonably take Risinger's own reported 3.3\% figure as a starting point. $^{72}$

In trying to reach broader conclusions about system-wide error rates, it is important to understand that Risinger's data comes from capital rape-murder cases, (and it is worth noting that comparable error rates in capital cases have been reported in one other recent study ${ }^{73}$ ). This rate of reported exonerations in capital cases is far higher than for any other category of criminal conviction - by a disproportion of about 130 to $1{ }^{74}$ This may be, in part, because such significant resources are devoted to litigating capital cases. But beyond that, many in the innocence movement have

66. The National Registry of Exonerations includes as an "exonerated" person any person who is convicted, has the conviction overturned, and then is acquitted on retrial. See Glossary, NAT'L REGISTRY EXONERATIONS, https://www.law.umich.edu/special/exoneration/Pages/glossary.aspx (last visited Oct. 2, 2018). This broad definition results in the inclusion of many people who would seem highly likely to be factually guilty. See infra note 174 (discussing similarly problematic Death Penalty Information Center list of innocents).

67. See, e.g., supra note 64 (discussing Urban Institute study).

68. Risinger, supra note 53, at 773-74.

69. See Samuel R. Gross et al., Rate of False Conviction of Criminal Defendants Who Are Sentenced to Death, 111 Proc. NAT'L ACAD. SCI. 7230, 7233 (2014) (“[Risinger's $3.3 \%$ estimate], however, is based on a small number of exonerations $(\mathrm{n}=11) . ")$.

70. Risinger, supra note 53, at 783.

71. Id. at 780 .

72. It is also possible to fold Risinger's 5\% maximum error rate into the calculation, as discussed in infra notes 172-174 and accompanying text.

73. See Gross et al., supra note 73, at 7233 (4.1\% error-rate figure, with sensitivity analysis extending both higher and lower).

74. See id. (death sentences represent less than $0.10 \%$ of prison sentences in the United States, but they accounted for about $12 \%$ of known exonerations of innocence defendants from 1989 through early 2012); see also Gross, supra note 12, at 757 tbl. 1 (collecting exonerations by crime in the National Registry). 
suggested that capital cases may, paradoxically, produce higher error rates than other types of cases. ${ }^{75}$ And even passing by that troubling possibility, rape cases also may be more error prone than other types of cases. ${ }^{76}$

Risinger derived his error-rate figure by narrowing the general category of capital cases to those involving both a stranger rape and an intentional murder. ${ }^{77}$ These cases appear to be one of the primary types of cases where wrongful convictions have been discovered through DNA. And most important for present purposes, these are also the types of cases where wrongful convictions are disproportionately likely to occur. As Professor Gross has explained, in murder cases "extraordinary pressure [mounts] to secure convictions for [such] heinous crimes." ${ }^{78}$ In addition, the police may be more prone to misidentifying innocent people as perpetrators given the unavailability of victims to provide first-hand information. Police also devote tremendous resources to solving murders, unlike other crimes of violence. ${ }^{79}$ The net result of these factors may well be that the risk of a wrongful conviction is, unexpectedly, greater for rape-homicides than for less serious crimes.

In a significant recent article, Professor Gross has helpfully calculated an estimated "relative exoneration" rate for various crimes by looking at the number of exonerations in the National Registry of Exonerations (an important private website he created that tries to track cases of wrongful convictions ${ }^{80}$ ) for various crime categories divided by the total number of convictions for those crime categories. ${ }^{81}$ For the years 1996 to 2004, setting robbery as the base from which to calculate

75. See, e.g., Samuel R. Gross, The Risks of Death: Why Erroneous Convictions Are Common in Capital Cases, 44 Buff. L. Rev. 469, 474-97 (1996); Gross et al., supra note 73 , at 7235 (" $[\mathrm{T}]$ here are theoretical reasons to believe that the rate of false conviction may be higher for murders in general, and for capital murders in particular, than for other felony convictions, primarily because the authorities are more likely to pursue difficult cases with weak evidence of guilt if one or more people have been killed."); Scott Phillips \& Jamie Richardson, The Worst of the Worst: Heinous Crimes and Erroneous Evidence, 45 HoFSTRA L. REv. 417, 421 (2016) (suggesting that the "worst of the worst crimes" produce the "worst of the worst evidence").

76. See GARRETT, supra note 35, at 184; Brandon L. Garrett, Judging Innocence, 108 Colum. L. REV. 55, 103 (2008) (noting high rates of acquittals in rape trials, as well as high attrition rates in other ways).

77. Risinger, supra note 53, at 770-72.

78. See Gross et al., supra note 54, at 532.

79. $I d$. at 542 .

80. See NAT'L REGISTRY EXONERATIONS, https://www.law.umich.edu/special/exoneration/Pages/about.aspx (last visited Jan. 2, 2018). According to its website, the Registry attempts to provide comprehensive information on exonerations of innocent criminal defendants to prevent future false convictions. Our Mission, NAT'L REGISTRY EXONERATIONS, https://www.law.umich.edu/special/exoneration/Pages/mission.aspx (last visited Oct. 19, 2018). The helpful website lists close to 2,000 cases, which are searchable in various ways. Browse Cases, NAT'L REGISTRY EXONERATIONS, https://www.law.umich.edu/special/exoneration/Pages/browse.aspx (last visited Oct. 19, 2108). One problem with the Registry is that it appears to use a very loose definition of who counts as an innocent person. See infra note 174.

81. Gross, supra note 12, at 766. 
relative exoneration rates, Gross determined the exoneration rate for rape was 8.5 times higher, the exoneration rate for noncapital murder 37 times higher, and the exoneration rate for death sentences 210 times higher. ${ }^{82}$

The issues raised by these numbers are important. Recall that Risinger's error-rate estimate rested on a sample of death sentences. If we take Gross's numbers as demonstrating that the error rate for capital sentences is more than 200 times higher than that for robbery - and that robbery crimes are far more typical than are capital cases - then a more broadly applicable error-rate estimate would need to be reduced dramatically.

While Professor Gross advances reasons for believing that discovered error rates in capital cases may be higher than for other crimes, it seems unlikely the actual rate would be higher by a factor of 200. A significant reason for these reported disparities is probably the difference in detecting wrongful convictions. Capital cases received extraordinary scrutiny, not only by defense attorneys and innocence projects, but also by governors and state and federal judges. ${ }^{83}$ The result is that an error in a death penalty case is far more likely to be detected. ${ }^{84}$ Similarly, with regard to rape cases, the availability of physical evidence left at the scene of the rape might permit exonerations through DNA testing or other means that are not possible for most robberies. ${ }^{85}$

My interest here is in reaching a figure not just for trials of certain capital rape-murders but for the broader category of all violent crimes. Most reported exonerations (about 82\%) have been for violent crimes. ${ }^{86}$ Violent crimes are conventionally defined (under the FBI's Uniform Crime Reports definition) as comprising murder and nonnegligent manslaughter, forcible rape, robbery, and aggravated assault. ${ }^{87}$ Of all arrests for violent crimes, almost 3 out of $4(74 \%)$ are for aggravated assault ${ }^{88}$ so it may be useful to compare the typical investigation of a capital rape-murder with that of an aggravated assault.

As a representative example of a capital rape-murder investigation, we can simply take the first of the eleven cases in Risinger's sample: Nicholas Yarris ${ }^{89}$ In

$\begin{array}{ll}\text { 82. } & I d . \\ \text { 83. } & I d . \\ \text { 84. } & I d . \\ \text { 85. } & I d .\end{array}$

86. Id. at 757. Of course, this is not to assert that wrongful convictions are less likely to occur for nonviolent crime cases. It could be that more resources are devoted to identifying wrongful convictions in violent crime cases because the collateral consequences of such an error (e.g., a lengthy term of imprisonment) are much greater.

87. See, e.g., Violent Crime, FBI: UNIFORM CRIME REP. 2017, https://ucr.fbi.gov/crime-in-the-u.s/2017/crime-in-the-u.s.-2017/topic-pages/violent-crime (last visited Oct. 19, 2018).

88. See Table 29: Estimated Number of Arrests, FBI: UnIFORM CRIME ReP. 2010 (last visited Oct. 19, 2018). An additional $20 \%$ are for robbery, and robbers may be more likely to be sent to prison and spend more time once sent there. See Gross et al., supra note 54, at 529 (noting more state prisoners incarcerated for robbery than assault).

89. See generally Commonwealth v. Yarris, 549 A.2d 513 (Pa. 1988). In an effort to avoid cherry picking, I chose the Yarris case for close analysis, simply because it was the first one Risinger lists in his sample, see Risinger, supra note 53, at 770-71 n.14, and because 
1981, a few days after the police discovered the body of a woman who had been brutally raped and murdered, an officer stopped Yarris for a traffic violation. ${ }^{90}$ The routine stop escalated into a violent confrontation between Yarris (who was addicted to methamphetamine) and the patrolman and ended in Yarris's arrest for trying to kill the officer. ${ }^{91}$ While under arrest for this offense, in a gambit to gain his freedom Yarris accused an acquaintance of committing the earlier rape-murder (an accusation, according to Yarris, which was the product of police coercion). ${ }^{92}$ When police excluded the acquaintance as a viable candidate, Yarris became the prime suspect. ${ }^{93}$ Conventional serological testing was performed on the rape kit, the results of which could not definitely exclude Yarris. ${ }^{94}$ In 1982, prosecutors convicted Yarris by relying on the ambiguous biological evidence, as well as the testimony of a jailhouse informant and the victim's coworkers, who identified Yarris as the man seen harassing the victim shortly before she was killed..$^{95}$ After the conviction, it was suggested that the prosecution may have withheld exculpatory evidence from the defense - gloves that did not fit Yarris, which were connected to the murder. ${ }^{96}$ Yarris was ultimately released in 2004 based on DNA evidence that excluded him. ${ }^{97}$ (Yarris, however, was for much of this time simultaneously serving a 30-year prison sentence for a prison escape in Florida.) $)^{98}$

The Yarris case involves at least five risk factors for a wrongful conviction: (1) shaky eyewitness identification; (2) possibly coerced statements during custody; (3) withheld exculpatory evidence; (4) a jailhouse informant; and (5) inconclusive but seemingly inculpatory forensic evidence. ${ }^{99}$ Such risk factors are not present in typical criminal investigations for more routine crimes such as aggravated assault. The criminology literature persuasively documents that most serious, reported crimes receive only superficial attention from investigators. ${ }^{100}$ "The single most important determinant of whether a crime will be solved is the information the victim supplies immediately to the responding patrol officer." ${ }^{101}$ If police are unable to obtain information uniquely identifying the perpetrator when they first receive a report of a crime, the perpetrator by and large will never be subsequently

on initial examination it appeared to be generally representative of the other cases in Risinger's sample. For citations to additional authorities setting out the facts of the case, see the Appendix below.

90. Nicholas Yarris, NAT'L REGISTRY EXONERATIONS, https://www.law.umich.edu/special/exoneration/Pages/casedetail.aspx?caseid=3771 (last visited Oct. 2, 2018).

91. Id.

92. Id.

93. Id.

94. Id.

95. Id.

96. Id.

97. Id.

98. Id.

99. Id.; see also Yarris v. County of Delaware, 465 F.3d 129 (3d Cir. 2006).

100. John E. Eck, Solving Crimes: The Investigation of Burglary and ROBBERY 16 (1983).

101. Id. at 24 (citing [1 Summary and Policy Implications] Peter W. Greenwood \& Joan Petersilia, The Criminal Investigation Process (1975)). 
identified. ${ }^{102}$ Generally speaking, "if a suspect is neither known to the victim nor arrested at the scene of the crime, the chances of ever arresting him are very slim." 103

Confirming this conclusion, one widely cited study found that of ten aggravated assault cases that police had solved, all ten were solved by "routine initial ID," and none were solved by more extended techniques such as a photo ID lineup, interrogation, fingerprints, or other forms of investigation. ${ }^{104} \mathrm{~A}$ much larger sample of cases in Kansas found that $94 \%$ of the aggravated assault cases were solved through initial identification. ${ }^{105}$ According to the Rand researchers who conducted the study, this data "again confirm that the great majority of cleared crimes are solved because the identity of the perpetrator is already known when the crime report reaches the investigator."106

Clearance rates for assault cases tend to be higher than other categories of common crimes - e.g., burglaries - because police often immediately receive a report of who committed the assault. For example, one study reported that police had a named suspect in $75 \%$ of the assault cases (but only $5 \%$ of burglary cases). ${ }^{107}$ Because of the fact that the victim and offender are often immediately known to each other in the aggravated assault crimes (or a suspect is immediately apprehended at the scene), investigations of the crimes are frequently straightforward affairs, and arrests occur quickly — often in less than one hour, as reported in one study. ${ }^{108}$ Many of the offenders were using alcohol at the time of the crime. ${ }^{109}$ For all these reasons, aggravated assaults are solved (or "cleared by arrest" in the nomenclature of the Uniform Crime Reports) about $56.4 \%$ of the time, a higher rate than any other crime apart from homicide (where significant resources are invested to increase clearance rates). ${ }^{110}$

The fact that police clear aggravated assault cases rapidly based on initial information helps paint a picture of typical assault cases. They often involve such things as bar-room fights or escalating domestic violence situations, where determining "whodunit" is not the question. Taking error rates from complex rape-

102. Id.

103. U.S. President's COMM'N ON LAW EnF'T \& Administration of Justice, TASK ForCE REPORT: SCIENCE AND TECHNOLOGY 8 (1967).

104. [3 Observations and Analysis] Peter W. Greenwood, Jan M. Chaiken, Joan Petersilia \& Linda Prusoff, The Criminal Investigation Process 66-77 (1975).

105. Id. at 77.

106. Id. at 78 .

107. Herbert H. Isaacs, A Study of Communications, Crimes, and Arrests in Metropolitan Police Department, in TASk Force Report: Science AND TeChnology, supra note 103 , at $88,97$.

108. See Arnita D. Varnedoe, Characteristics of Offenders Arrested for Aggravated Assault: A Test of Easterlin's Hypothesis 8 (May 1, 1987) (unpublished M.A thesis, Atlanta University),

http://digitalcommons.auctr.edu/cgi/viewcontent.cgi? article=3091\&context=dissertations .

109. See, e.g., Alcohol \& Crime: Data from 2002 to 2008, BuREAu Just. Stat., https://www.bjs.gov/content/acf/apt1_crimes_by_type.cfm (last visited Sep. 13, 2018) (approximately $21.1 \%$ of aggravated assaults in 2008 involved offenders using alcohol)

110. Table 25: Percent of Offenses Cleared by Arrest or Exceptional Means, FBI: UNIFORM CRIME REP. 2010, https:/ucr.fbi.gov/crime-in-the-u.s/2010/crime-in-the-u.s.2010/tables/10tbl25.xls (last visited Oct. 19, 2018). 
murder investigations and applying them to these kinds of simple cases will invariably and significantly overstate the frequency of wrongful convictions.

In this connection, it is interesting to observe that within the National Registry of Exonerations, assault cases are only a tiny fraction - about 4\%. ${ }^{11}$ Given the large number of assaults prosecuted in the criminal justice system, this appears to suggest that assault cases are particularly unlikely to produce wrongful convictions. ${ }^{112}$

\section{2. $\quad$ The Typicality of the Error-Rate Samples}

In trying to determine a more broadly applicable wrongful conviction trial rate, it is also instructive to consider whether Risinger's error-rate figure is even typical of homicide cases. It seems likely that, even for such crimes, Risinger's sample significantly overstates the frequency of wrongful convictions. To take one straightforward example, consider manslaughter cases-i.e., cases in which the defendant concedes that he killed the victim but argues that he was provoked or acting in self-defense. For such cases, the wrongful conviction rate- specifically the "wrong person" conviction rate at issue in this article ${ }^{113}$ - is, by definition, $0.0 \%$, because the identity of the killer in such cases is undisputed.

For an illustration of this point, we might look to the 267 cases discussed in Professor Nourse's well-known article regarding "passion murder cases." 114 She collected all intimate-homicide cases from 1980 to 1995 in which a murder defendant asserted a defense based on the Model Penal Code's defense of Extreme Emotional Disturbance (EED) compared to samples drawn from jurisdictions following more traditional definitions of the defense. ${ }^{115}$ She provided a brief summary of each of the cases in her study. For example, the very first case listed involved the following situation:

111. See Gross, supra note 12, at 757. Note that this figure is apparently for all assaults, both aggravated and simple, which further underscores how underrepresented aggravated assaults are in the Registry.

112. This conclusion is not free from doubt. It may be that assault cases are unlikely to leave behind physical evidence that can be analyzed and later exonerate a suspect. See Gross \& O'Brien, supra note 38, at 938 (noting that robberies are likely underrepresented among exonerees compared to rapes due to the presence of physical evidence in rape cases). But some assaults might leave behind physical evidence. And it is interesting that assaults are also underrepresented compared to robberies - a kind of crime for which the presence of physical evidence might be roughly comparable. In the National Registry of Exonerations, roughly $5 \%$ of all cases are robberies and $4 \%$ are assaults of all varieties. Gross, supra note 12 , at 757 . Yet the number of robbery arrests is a fraction of the number of assault arrestsless than 10\%. See, e.g., Table 18: Estimated Number of Arrests, FBI: UNIFORM CRIME REP. 2016, https://ucr.fbi.gov/crime-in-the-u.s/2016/crime-in-the-u.s.-2016/topicpages/tables/table-18 (last visited Oct. 19, 2018) (95,000 arrests for robbery; 383,000 for aggravated assault; and 1,078,000 arrests for "other assaults").

113. See supra notes 14-19 and accompanying text.

114. Victoria Nourse, Passion's Progress: Modern Law Reform and the Provocation Defense, 106 YALE L.J. 1331 (1997).

115. Id. at 1345-47. It appears that her sample consisted entirely of trials, not pleas. See id. at 1350 . 
[The] victim sought to terminate her relationship with the defendant, who had a history of psychological problems. According to the defendant's testimony, the victim attended a party with the defendant and thereafter told the defendant not to believe that they would get back together. As they were driving home, the defendant got angry, pulled a shotgun from the trunk, and killed [her]. ${ }^{116}$

If we use this collection of homicide cases to estimate a more broadly applicable trial error rate, the rate would be $0.0 \%$. To be sure, a jury may mistakenly reject the claims of a defendant seeking a reduction from murder to manslaughter. But no one argues that these kinds of mistakes are the type of wrongful conviction under discussion. ${ }^{117}$ Thus, just as Risinger was able to compute an error rate for a "significant subset of cases" in the criminal justice system (capital rape-murder cases in the 1980s), ${ }^{118}$ it is possible to even more precisely calculate an error rate for a much larger number of cases: manslaughter cases, where the error rate is $0.0 \%$ and factually innocent people are in no way at risk of wrongful conviction. This "subset" of homicide cases vastly outnumbers the subset Risinger is examining. By some measures, manslaughter convictions are about as frequent as murder convictions ${ }^{119}$ (and capital murder convictions are, of course, a tiny fraction of all murder convictions).

This point can be readily extended to many other crimes. Indeed, it is quite likely that many violent crime cases do not present any realistic chance of a factually innocent person being convicted. In the bar-room-fight case, there may be no real dispute about who the two combatants were, but only a dispute about who was the first aggressor. Or, to take another common illustration, consider a defendant who admits he had sex with a woman and then later is charged with "date rape." He cannot be wrongfully convicted in the sense of being misidentified by the victim or through shoddy forensic evidence. Instead, the issue in the case will be his state of mind-did he knowingly coerce sex from an unwilling partner-which raises questions of legal innocence not factual innocence. ${ }^{120}$

Many important categories of cases in our criminal justice system involve situations where identifying whodunit is not the issue and thus "wrong person" convictions are not realistically possible. A partial list of the categories would include cases of:

- manslaughter, where the defendant argues he or she committed the killing but was provoked or disturbed;

116. Id. at 1415 (describing State v. Forrest, 578 A.2d 1066 (Conn. 1990) (internal citations and quotations omitted)).

117. See supra notes 14-19 and accompanying text (discussing definition of "wrongful conviction").

118. Risinger, supra note 53, at 767.

119. See Samuel H. Pillsbury, Judging Evil: Rethinking the Law of Murder AND MANSLAUGHTER 101 n.9 (1998).

120. See Risinger, supra note 53, at 762 n.2 (defining "factual innocence" as excluding situations where someone has performed the actus reus of the crime). 
- lovers' quarrels, romantic triangles, and other argument situations in the presence of unchallenged witnesses or where the defendant does not dispute the killing;

- killings and assaults where the defendant raises self-defense and imperfect self-defense claims;

- date rape and other sex offenses where the issue is not whether the defendant had sex with the alleged victim, but rather whether the defendant knowingly obtained nonconsensual sex;

- bar-room fights and other mutual-combat situations in public settings with multiple eyewitnesses;

- crimes where a defense of diminished capacity or insanity is presented;

- fraud where the defendant concedes the transactions but argues lack of fraudulent intent;

- possession (including drugs and firearms cases) where the defendant is caught red-handed and cannot plausibly dispute possession;

- domestic violence where the parties contest who was the first aggressor;

- immigration offenses where the defendant is illegally in the country; and

- drunk driving and other public order offenses.

This list could easily be expanded, but the essential point is that, for quantification of risk, we need to think carefully before directly extrapolating from an error rate in one kind of case to an error rate across the entire American criminal justice system. ${ }^{121}$ For present purposes, the key point is that applying the $3.3 \%$ errorrate figure from capital rape-murder cases will significantly overstate the trial error rate in more typical, violent crime cases where identification of the perpetrator is not the question.

The difficult issue is determining how much of an overstatement exists. Some measure may be provided by a recent National Crime Victimization Survey (based on reports from crime victims), which reveals that a minority (about 39.2\%) of total violent crimes were committed by strangers, including $42.3 \%$ of aggravated assaults, $51.7 \%$ of robberies, and $24.1 \%$ of rape/sexual assaults. ${ }^{122}$ Another measure comes from the Uniform Crime Reports (based on reports from local law enforcement agencies), which indicates that only about $21 \%$ of all homicides were committed by strangers. ${ }^{123}$ Taken together, the data show that most violent crimes do not involve unknown stranger perpetrators. And yet Risinger's sample of capital

121. Cf. Christopher Slobogin, Lessons from Inquisitorialism, 87 S. CAL. L. REV. 699, 702 (2014) (applying the Allen-Laudan error rate to one million state court convictions to produce 5,000 wrongful convictions a year); George C. Thomas III, Two Windows into Innocence, 7 ОhIо ST. J. CRIM. L. 575, 577-78 (2010) (applying 2\% error-rate figure from English plea-bargain practice to produce figure of 40,000 wrongful American felony convictions per year); see also Koppl \& Sacks, supra note 12, at 130-31 (discussing extrapolations from Risinger error rate).

122. ERika Harrell, U.S. Dep'T of Justice, Special Report: Violent Victimization COMmitted By StRANGers, 1993-2010, at 2 tbl.1 (2012), https://www.bjs.gov/content/pub/pdf/vvcs9310.pdf.

123. Alexia Cooper \& Erica L. Smith, Bureau of Justice Stat., Homicide TRENDS IN THE UNITED STATES, 1980-2008, at 18 (2011), https://www.bjs.gov/content/pub/pdf/htus8008.pdf. 
rape-murders involves a far higher percentage of cases involving stranger perpetrators; indeed, it appears that all of his 11 cases involved stranger crimes, like the one Yarris was suspected of committing, ${ }^{124}$ thus requiring extensive law enforcement efforts to solve.

Stranger-perpetrated crimes are by far the most likely areas for wrongful convictions. $^{125}$ For example, one of the most common causes of wrongful convictions - eyewitness misidentification ${ }^{126}$ - is, according to Professor Gross, "almost entirely restricted to crimes committed by strangers." 127

In contrast, most aggravated assaults are not committed by strangers. ${ }^{128}$ And even among the stranger-perpetrated cases in aggravated assault cases, "whodunit" issues will not always be present - such as when a drunken man at a bar gets in a fight and is apprehended in the presence of numerous eyewitnesses. ${ }^{129}$

One way of deriving a figure for the overstatement is taking Risinger's $3.3 \%$ error rate in capital rape-murder cases (which are almost exclusively strangerperpetrated cases) and noting that only $21 \%$ of homicides are committed by strangers. ${ }^{130}$ Even among stranger-perpetrated killings, many of the cases will not be candidates for wrongful conviction (such as when the defendant/stranger claims insanity or self-defense), although there will certainly be some nonstrangerperpetrated cases where wrongful convictions are possible.

Considering all this data, it is obvious that Risinger's 3.3\% error-rate figure vastly overstates the error rate for violent crime cases. Using homicides overstates the likely error rate, and many violent crime cases do not contain the kinds of convictions - e.g., crimes perpetrated by strangers - where wrongful convictions are likely to occur. Evaluating the data presented above in light of these facts, it seems a reasonable (and perhaps slightly overstated) estimate to conclude that it is unlikely for the conditions for wrongful convictions to exist in more than about $25 \%$ of violent crime cases.

In sum, we can, for extrapolation purposes, ${ }^{131}$ reduce Risinger's $3.3 \%$ trial error-rate figure as ultimately suggesting a (possibly overstated) figure across all violent crimes of about $0.82 \%$-i.e., $25 \%$ of Risinger's reported $3.3 \%$ error rate.

124. See Risinger, supra note 53, at 770 n.14 (listing cases).

125. See Gross \& O'Brien, supra note 38, at 940-41 (raising this point).

126. See Garrett, supra note 24 , at 45 (noting $72 \%$ of DNA-exoneration cases involved eyewitness misidentification).

127. Gross et al., supra note 54, at 530.

128. See supra note 122 and accompanying text.

129. Many aggravated assault cases involve close-quarters combat. About $27 \%$ of aggravated assaults involve personal weapons such as hands, fists, and feet, and 19\% involved knives or other cutting instruments. See Table 22: Aggravated Assault, FBI: UnIFORM CRIME REP. 2011, https://ucr.fbi.gov/crime-in-the-u.s/2011/crime-in-the-u.s.-2011/tables/table-22 (last visited Oct. 19, 2018).

130. COOPER \& SMITH, supra note 123, at 18 .

131. The extrapolation here assumes that the figures cited above, which involve all cases (not just trial) are roughly applicable to trial cases, for which we are calculating the error rate. 


\section{Current Error Rates in Light of Advancing DNA and Other Improved Forensic Technologies}

One final factor remaining to be considered is that Risinger drew his sample from crimes committed long ago. Risinger's sample consists of a group of capital rape-murders in the 1980s. ${ }^{132}$ It was this unique time period that then permitted Risinger to find examples of errors - errors detected through subsequently developed DNA technology. Indeed, all of the wrongful convictions that Risinger identified came (at least in part) from so-called "DNA exonerations." 133

But, of course, we now live in a world where DNA technology is widely available to law enforcement ${ }^{134}$ and certainly would be used in any capital rapemurder prosecution instituted. And given the greater precision of DNA technology over older technologies, if these same cases arose today, DNA evidence would have prevented the initial wrongful prosecution - and even if a prosecution was initiated, any ultimate wrongful conviction-from ever occurring.

As an illustration of this point, consider the Nicholas Yarris case described above. ${ }^{135}$ At the crime scene of the 1981 rape-murder, police collected biological evidence from the victim's body, including sperm samples and fingernail scrapings. ${ }^{136}$ Police also found gloves believed to have been left by the perpetrator in the victim's car. ${ }^{137}$ Police then performed conventional serological testing on the evidence, which could not exclude Yarris. ${ }^{138}$ Indeed, at trial, the prosecution affirmatively argued that the testing of blood and body fluids placed Yarris within the approximately $13 \%$ of the male population who might have raped the victim. ${ }^{139}$

After Yarris was convicted, he began an effort to obtain DNA testing of the evidence. ${ }^{140}$ In 2003, Dr. Edward Blake conducted retesting of the evidence, which showed that profiles obtained from the gloves and the spermatozoa evidence appeared to originate from the same person. ${ }^{141}$ Yarris was excluded from all biological material connected with the crime. ${ }^{142}$

Of course, if the Yarris case were to unfold today, DNA testing would be readily available to the police and prosecution at the outset. And Yarris would thus be excluded as a possible perpetrator, and rape-murder charges would never be

132. See Risinger, supra note 53, at 770-72.

133. See the Appendix to this Article.

134. All 50 states and Congress have adopted some form of post-conviction DNA legislation, and the technology is now widely used. See Barry C. Scheck, Conviction Integrity Units Revisited, 14 OHIO ST. J. CRIM. L. 705, 715 (2017).

135. Commonwealth v. Yarris, 549 A.2d 513, 522 (Pa. 1988) (discussed in supra note 89-98 and accompanying text).

136. Nicholas Yarris, supra note 90.

137. Id.

138. Id.

139. Yarris, 549 A.2d at 522.

140. Mario Cacciottolo, Nick Yarris: "How I Survived 22 Years on Death Row", BBC NEws (Nov. 16, 2016), http://www.bbc.com/news/world-us-canada-37974904.

141. Id.

142. Id.; see also Cacciottolo, supra note 140. See generally NICK YARRIS, THE Fear of 13: Countdown to Execution: My Fight for Survival on Death Row (2016). 
pursued against him. In other words, unsurprisingly, the criminal justice system today will be more accurate than it was back in the early 1980s in handling cases like Yarris's.

The Yarris case is typical of the 11 cases in the Risinger sample-i.e., in all of the other 10 cases it is virtually impossible that any of the defendants would be convicted today given the greater power of DNA technology to pinpoint connections (or lack thereof) between a suspect and crime scene evidence. The Appendix to this Article reviews each of the cases and explains this conclusion.

This march-of-science point has tremendous implications for calculating a current justice system error rate. For example, anyone relying exclusively on Risinger's 3.3\% error rate as a basis for extrapolating errors across the system would need to substitute a different error rate- $0.0 \%$ - as the empirically grounded component of the Risinger figure applicable today. And other studies similar to Risinger's relying on erroneous convictions from long ago would produce an overstated error rate if used to estimate a present-day wrongful conviction rate. ${ }^{143}$

Looking more broadly beyond just the Risinger sample, an important point is that we should expect the wrongful conviction rate in this country to have exhibited a decisive downward trend over the last several decades. Although this trend is rarely discussed in the innocence literature, ${ }^{144}$ innocence scholars can quite properly and proudly take credit for initiating many recent reforms designed to prevent the conviction of the innocent in America's criminal justice system. As one recent review concluded, the Innocence Movement has resulted in "widespread systemic reform, including greater DNA collection and testing, changes to police investigative procedures, rules to prevent prosecutorial misconduct, increased funding for capital defense attorneys, and higher standards for attorneys representing these clients." ${ }^{145}$ While these reforms are imperfect, they certainly have improved how cases involving innocent people are processed in the criminal justice system and should be producing real reductions from whatever the wrongful conviction rate previously was. ${ }^{146}$

143. See, e.g., Gross \& O'Brien, supra note 38, at 946 (estimating 2.3\% wrongful conviction rate in death sentences imposed between 1973 and 1989); Gross et al., supra note 69, at 7233 (estimating 4.1\% "exoneration" rate in death sentences imposed between 1973 and 2004). Gross et al.'s estimates are discussed in more detail at infra note 173.

144. One exception is the brief reference to trends by Professor Gross and his colleagues in their recent study of death-sentence error rates. They raise the possibility that "the death-sentencing rate of innocent defendants has changed over time." Gross et al., supra note 69 , at 7235 . However, they conclude that "[n]o specific evidence points in that direction, but the number and the distribution of death sentences have changed dramatically in the past 15 years." Id. They cite trends on the number of death sentences imposed, which moved from 137 in 1977, to a high of 315 in 1996, to 138 in 2004 (the last year of their study). Id. at n.22. These dramatic fluctuations in the number of death sentences, for reasons presumably having little to do with reliability issues, mean that a search for trend lines must rely on data other than that collected in death penalty cases.

145. Lara A. Bazelon, The Long Goodbye: After the Innocence Movement, Does the Attorney-Client Relationship Ever End?, 106 J. CRIM. L. \& CRIMINOLOGY 681, 700-01 (2016) (internal quotations omitted).

146. Changes have also been made to post-conviction procedures to help exonerate 
As an illustration, consider how one important cause of wrongful convictions - false confessions ${ }^{147}$ - has been treated over time. Beginning around the 1990s, increasing awareness of false confessions led to a call for recording police interrogations. ${ }^{148}$ Several scholars (including me) argued that recording could help prevent wrongful convictions from false confessions (particularly of intellectually disabled suspects) by restraining improper police coercion and allowing later impartial reconstruction of what happened during a custodial interrogation. ${ }^{149}$ While recording is not universally used today, it is clearly spreading among police agencies: one recent survey reports that "[s]ince 2003, the number of states requiring law enforcement officers to electronically record some or all interviews conducted with suspects in their custody has grown from two to at least twenty-two." 150 This trend is likely to accelerate as the use of body cameras becomes more widespread among law enforcement. ${ }^{151}$

Law enforcement training on avoiding false confessions has also significantly expanded in recent years; for example, the most widely used police interrogation training manual (the Inbau-Reid Manual) had no discussion of the topic of false confessions in its 1986 edition but an entire 40-page chapter in its 2013 edition. ${ }^{152}$

Defense attorneys, too, are now much better positioned to explain to juries how a suspect might have falsely confessed. In appropriate cases, false confession experts are sometimes allowed to testify and can help the jury understand, for example, the unique psychological disabilities that may have caused a person to falsely confess. ${ }^{153}$

the innocent after a wrongful conviction. See Brandon L. Garrett, Towards an International Right to Claim Innocence, 105 CALIF. L. REv. 1173, 1183 (2017). Because such reforms do not affect the initial wrongful conviction rate, they are not considered here.

147. See Garrett, supra note 24, at 46 (confession evidence introduced in $21 \%$ of DNA-exoneration cases).

148. Craig M. Bradley, The Failure of the Criminal Procedure Revolution 85 (1993).

149. See Paul G. Cassell, Miranda's Social Costs: An Empirical Reassessment, 90 Nw. U. L. REv. 387, 486-89 (1996) (calling for videotaping as a replacement for Miranda and citing others who had reached a similar conclusion); Cassell, supra note 46, at 553-54 (arguing for videotaping to protect the innocent); see also Cassell, supra note 17, at 583-90 (discussing intellectual disabilities and false confessions).

150. Dep't of Justice, New Department Policy Concerning Electronic Recording of Statements, 128 HARV. L. REV. 1552, 1552 (2015).

151. See Paul G. Cassell \& Richard Fowles, Still Handcuffing the Cops? A Review of Fifty Years of Empirical Evidence of Miranda's Harmful Effects on Law Enforcement, 97 B.U. L. REV. 685, 839-40 (2017).

152. Compare Fred E. INBAU ET AL., CRIMINAL INTERROGATION AND CONFESSIONS (3d ed. 1986) (no entry for "false confessions" in index), with FrED E. INBAU ET. AL., CRIMINAL INTERROGATION AND CONFESSIONS 339-78 (5th ed. 2013) (discussing "distinguishing between true and false confessions," summarizing false confession research, and providing ways to evaluate confession trustworthiness).

153. See, e.g., Pritchett v. Commonwealth, 557 S.E.2d 205, 207-08 (Va. 2002) (testimony of defense expert witness on issue of defendant's "mental retardation" and the susceptibility of such persons to suggestive police interrogation was admissible). Indeed, the 
The area of false confessions is not the only one where advances in technology and legal procedures should be producing reductions in wrongful convictions. In the interests of brevity, just a quick survey of some other illustrative advancements may be useful.

Flawed forensic science has been a leading cause of wrongful convictions, ${ }^{154}$ and forensic science is an area of considerable recent improvement in the system. ${ }^{155}$ DNA technology is just one example of the way in which the criminal justice system now possesses much more accurate tools for separating guilty from innocent suspects, particularly in the kinds of high profile cases that create pressures that might produce wrongful convictions. ${ }^{156}$ And as new technologies have marched on, jurors have come to expect more rigorous scientific investigation before returning guilty verdicts - the "CSI effect." 157

Concern about innocence issues has also led to several reform commissions. For example, in 2009, the National Research Council of the National Academy of Sciences published an important report entitled Strengthening Forensic Science in the United States: A Path Forward. ${ }^{158}$ The report contained many recommendations for improving forensic science, including many areas (such as odontology/bite marks disciplines) which had created risks of wrongful convictions. ${ }^{159}$ In 2014, the Council released a comprehensive report on the science of eyewitness identification practices in the United States. The report, Identifying the Culprit: Assessing Eyewitness Identification, ${ }^{160}$ recommended that law enforcement adopt a series of practices designed to reduce eyewitness mistakesanother common cause of wrongful convictions. ${ }^{161}$

problem today may be that some defense false confession experts go too far in claiming that confessions are false. See, e.g., United States v. Phillipos, 849 F.3d 464, 471-72 (1st Cir. 2017) (affirming district court decision to exclude false confession testimony from Richard Leo because it would "introduce the jury ... to a kind of faux science"), cert. denied, $138 \mathrm{~S}$. Ct. 683 (2018).

154. See Garrett, supra note 24 , at 48 (74\% of DNA-exoneration cases involved forensic testimony); $c f$. Gross, supra note 12, at 770 (using a different methodology and finding "perjury or false accusation" to be the leading cause).

155. See, e.g., Simon A. Cole, Scandal, Fraud, and the Reform of Forensic Science: The Case of Fingerprint Analysis, 119 W. VA. L. REV. 523, 524 (2016).

156. See Donald A. Dripps, Miranda for the Next Fifty Years: Why the Fifth Amendment Should Go Fourth, 97 B.U. L. REV. 893, 921 (2017).

157. See Hon. Donald E. Shelto, The "CSI Effect": Does it Really Exist?, NAT'L INST. JUST. (Mar. 17, 2018) https://www.nij.gov/journals/259/pages/csi-effect.aspx.

158. See generally NAT'L Research Council of the NAT'L ACAdemies, Strengthening Forensic Science in the United States: A Path Forward (2009), https://www.ncjrs.gov/pdffiles1/nij/grants/228091.pdf.

159. Id.

160. See generally NAT'L RESEARCH COUNCIL OF THE NAT'L ACADEMIES, IDENTIFYING THE CULPRIT: ASSESSING EYEWITNESS IDENTIFICATION (2014), https://www.nap.edu/catalog/18891/identifying-the-culprit-assessing-eyewitnessidentification.

161. See Garrett, supra note 24, at 46 (eyewitness identification evidence introduced in $72 \%$ of DNA-exoneration cases). 
Law enforcement agencies have also looked at their own practices. For example, in 2016, the Justice Department and the FBI formally acknowledged that nearly every microscopic-hair-comparison examiner had given testimony that overstated matches in a way that favored the prosecution. ${ }^{162}$ The Department committed to working to improve its practices in the future. ${ }^{163}$ In 2014 in Houston, after a series of problems with a police-operated crime lab, a new and independent laboratory (the Houston Forensic Science Center) opened. ${ }^{164}$

States, too, have looked into preventing wrongful convictions. For example, the New York State Bar Association assembled a Task Force on Wrongful Convictions and in 2009 issued a report with a series of recommendations on criminal justice issues. ${ }^{165}$ The Texas Forensic Science Commission has taken a hard look at questionable forensic practices and has become, according to many accounts, a model for how to assess forensic evidence. ${ }^{166}$

Prosecutors have likewise made changes. Some large offices have established conviction-integrity programs specifically designed to prevent and correct wrongful convictions. ${ }^{167}$ One recent review of these programs by a leading innocence litigator, Barry Scheck, concluded that they "may have a surprisingly good chance of succeeding." 168

This is just a brief collection of what can fairly be described as a flurry of recent efforts throughout the criminal justice system addressing innocence issues. To be sure, progress in implementing innocence reforms has been uneven, ${ }^{169}$ and no

162. Spencer S. Hsu, FBI Admits Flaws in Hair Analysis Over Decades, WASH. Post (Apr. 18, 2015), https://www.washingtonpost.com/local/crime/fbi-overstated-forensichair-matches-in-nearly-all-criminal-trials-for-decades/2015/04/18/.

163. Id.

164. SAndra Guerra ThOMPson, Cops in Lab CoATs: Curbing Wrongful CONVICTIONS THROUGH INDEPENDENT FORENSIC LABORATORIES 222-23 (2015).

165. See generally N.Y. State Bar Ass'n, Final Report of the New York State BAR AsSOCIATION's TASK FORCE ON WRONGFUL CONVICTIONS (2009), https://www.nysba.org/wcreport.

166. See, e.g., Trevor Rosson, A New Remedy for Junk Science: Article 11.073 and Texas's Response to the Changing Landscape in the Forensic Sciences, 48 ST. MARY's L.J. 465,478 (2017) ("[T]oday the TFSC stands as a model for the nation in its determination to find solutions to problems in the forensic sciences.").

167. See, e.g., Ctr. On the Admin. Of Criminal LaW's Conviction Integrity Project, Establishing Conviction Integrity Programs in Prosecutors' Offices (2012),

http://www.law.nyu.edu/sites/default/files/upload_documents/Establishing_Conviction_Inte grity_Programs_FinalReport_ecm_pro_073583.pdf; Eric S. Fish, Prosecutorial Constitutionalism, 90 S. CAL. L. REV. 237, 304 (2017) (“'A] growing number of prosecutors' offices have established 'conviction integrity units' that seek to identify wrongfully convicted prisoners. Such units exist in twelve states, as well as Washington D.C, and more are being added.").

168. Scheck, supra note 134 , at 713.

169. Garrett, supra note 24, at 47; cf. Notice of Public Comment on Advancing Forensic Science, 82 Fed. Reg. 17879 (Apr. 13, 2017) (announcing that the National Commission on Forensic Science would not be extended for a third term, but seeking public comment on how to advance the practice of forensic science in light of work by the 
one believes that the problem of wrongful convictions has been eliminated. But the salient point is that clear progress is being made toward addressing the wrongful conviction problem. And that progress should mean that the wrongful conviction rate in America today is noticeably lower than it was in earlier decades.

As a means of trying to (cautiously) identify what kind of trial error rate might exist in the system today, we can return to the Risinger sample. In highlighting 11 cases of wrongful conviction in his sample of cases from 1982 to 1989, Risinger also reviewed the other cases in his sample to try to determine if additional errors beyond those revealed by DNA testing might occur. ${ }^{170}$ Risinger identified his $3.3 \%$ error rate as the "conservative minimum factual innocence rate" in his sample-i.e., the floor for the error rate. ${ }^{171}$ But he also estimated a "fairly generous likely maximum" error-i.e., the ceiling. Risinger put this figure at 5\%. ${ }^{172}$

Risinger's estimate allows us to make a further correction of our error rate - a correction that might even be regarded as conservative. Rather than starting at only the $3.3 \%$ "minimum" error rate that Risinger identified, we would begin at the $5 \%$ "likely maximum" rate that he identified based on cases prosecuted in the $1980 \mathrm{~s}$. But as a measure of the current wrongful conviction rate, we would have to reduce that maximum by backing out cases that, in 2018, would never lead to wrongful convictions because of improvements in DNA (not to mention other forms of forensic science). Thus, at a minimum, we would back out the $3.3 \%$ of cases where widespread DNA technology would today exclude the suspect and prevent a wrongful conviction. This means that, even starting at Risinger's maximum figure of $5 \%$, what remains is only a $1.7 \%$ (5\% minus $3.3 \%)$ error rate for cases going to trial now. ${ }^{173}$

Commission and others).

170. Risinger, supra note 53, at 778-79.

171. Id. at 778 .

172. Id. at 780 .

173. As a "cross-check" to this $1.7 \%$ error rate derived from Risinger's original $5.0 \%$ figure, it is possible to compare what would happen if we make a similar adjustment to Gross et al.'s 4.1\% error-rate figure from death penalty cases from 1973 through 2004. See Gross et al., supra note 69 , at 7233 . Gross et al. counted as an exoneration any case on a list maintained by the Death Penalty Information Center (DPIC). See id. at 7231 (citing The Innocence List, DeATH PenAlty INFO. CTR., https://deathpenaltyinfo.org/innocence-listthose-freed-death-row (last visited Sep. 13, 2018)). It appears that a substantial portion of these exonerations (as in Risinger's sample) come as a result of DNA analysis. For example, while the 2014 study does not break out DNA exonerations separately, in an earlier study Gross reported that of all exonerations listed in the National Registry of Exonerations from 1989 through 2003 about 42\% came from DNA analysis. Gross et al., supra note 54, at 524. On the other hand, the DPIC attributes about $12 \%$ of its exonerations (as of 2004, apparently using more restrictive criteria) to DNA exonerations. Richard C. Dieter, Innocence and the Crisis in the American Death Penalty, Death Penalty Info. Ctr. (Sep. 2004), https://deathpenaltyinfo.org/innocence-and-crisis-american-death-penalty\#Sec05b. This suggests that, as in the case of Risinger's data, Gross et al.'s $4.1 \%$ figure would need to be reduced noticeably as a measure of current error rates. $I d$.

In addition and more worrisome, unlike Risinger's definition of DNA exonerations, the DPIC list that Gross et al. rely upon uses a much softer definition of "exoneration," which includes many people who had convictions overturned on procedural 
It might be objected that this adjustment fails to recognize that, even with improved DNA technologies, it might still be possible for an innocent person to wrongfully fall under suspicion. For example, in the Yarris case, as noted above, a jailhouse informant testified that Yarris made incriminating statements. ${ }^{174}$ Perhaps, it could be argued, that shaky testimony might be enough to obtain a conviction in the face of a DNA "exclusion." Such arguments seem implausible, but as a hedge

grounds after which prosecutors were unable to secure convictions by proof beyond a reasonable doubt. See The Innocence List, DeAth PenAlty Information Ctr., supra (including as "innocent" any person who is acquitted of a crime that placed them on death row). This loose definition opens the door to including many people as "innocent" who were not factually innocent. See Kansas v. Marsh, 548 U.S. 163, 196 (2006) (Scalia, J., concurring) (noting "mischaracterization of reversible error as actual innocence is endemic in abolitionist rhetoric" and criticizing DPIC list); see also Ward A. Campbell, Critique of DPIC List, http://www.prodeathpenalty.com/dpic.htm (last visited Jan. 12, 2018) (reviewing specific examples of people on DPIC list who do not appear to be "innocent" of the crimes for which they were convicted).

A few illustrations from the DPIC list demonstrate the problem:

(1) Jay C. Smith had his death sentence overturned due to a debatable Brady violation, but on later review of Smith's civil-rights suit the Third Circuit concluded: Our confidence in Smith's convictions for the murder of Susan Reinert and her child is not the least bit diminished by consideration [of the withheld evidence] . . . and Smith has therefore not established that he is entitled to compensation for the unethical conduct of some of those involved in the prosecution.

Smith v. Holtz, 210 F.3d 186, 193-94 (3d Cir. 2000), discussed in Marquis, supra note 17, at 521.

(2) John C. Skelton had his conviction overturned on grounds of insufficient evidence rather than actual innocence, with the (divided) appellate court explaining that "[a]lthough the evidence against appellant leads to strong suspicion or probability that [Skelton] committed [the crime], we cannot say that it excludes to a moral certainty every other reasonable hypothesis except [his] guilt." Skelton v. State, 795 S.W.2d 162, 169 (Tex. Crim. App. 1989) (emphasis added).

(3) Steven Smith had his conviction overturned on grounds of insufficient evidence, with the appellate court explaining:

While a not guilty finding is sometimes equated with a finding of innocence, that conclusion is erroneous. Courts do not find people guilty or innocent. They find them guilty or not guilty. A not guilty verdict expresses no view as to a defendant's innocence ... This case happens to be a murder case carrying a sentence of death against a defendant where the State has failed to meet its burden. People v. Smith, 708 N.E.2d 365, 371 (Ill. 1999).

(4) Robert Cox had his conviction overturned on grounds of insufficient evidence rather than innocence, while the reviewing court agreed that there was a "strong suspicion" that Cox had committed the murder. Cox v. State, 555 So.2d 352, 353 (Fla. 1990). Some significant downward adjustment of the DPIC figures appears to be reasonable to reflect this very soft measure of innocence.

In light of these two factors, it appears that substituting Gross et al.'s (lower) $4.1 \%$ error rate for Risinger's $5.0 \%$ error rate does not appear to make a great difference in the calculations offered here, and any substituted figure would certainly fall within the range of possible error rates calculated through reliance on the Risinger figure.

174. See supra note 99 and accompanying text. 
against this possibility — and, again, to be very conservative in the calculation - we might modestly increase the $1.7 \%$ current "maximum" figure suggested in the previous paragraph to a total of $2.0 \%$. This adjustment also allows for the possibility that Risinger may have underestimated the maximum rate to some degree. And if we substitute a $2.0 \%$ error rate (rather than Risinger's $3.3 \%$ ) into the calculations made in the previous Section, we arrive at the (again, possibly overstated) figure of a trial error rate of $0.50 \%$-i.e., $1 / 4$ of the $3.3 \%$ error rate, as discussed previously ${ }^{175}$ - across all violent crimes.

\section{The Ratio of Wrongful Convictions Through Trials and Guilty Pleas}

Once we determine an estimated error rate at trial, the next important issue that arises is how this rate applies to cases in which a conviction is obtained through a guilty plea. Given that the vast majority of cases are resolved by guilty pleas, the percentage of wrongful convictions in that larger pool will substantially influence the ultimate error-rate figure that is derived for the criminal justice system as whole.

It is clear that innocent people do, in some cases, plead guilty. ${ }^{176}$ The significant incentives that can be offered for a guilty plea-particularly in cases involving lengthy mandatory-minimum sentences - can place strong pressures on an innocent person to simply take a plea deal. A possible complicating fact, as discussed below, ${ }^{177}$ is that an innocent person may commit another crime in pleading guilty to a crime he did not commit - perjury during the plea colloquy in attesting under oath to his guilt. But for present purposes, the key point is that such wrongfulconviction-by-guilty-plea cases do exist.

The frequency with which innocent people plead guilty is debated. ${ }^{178} \mathrm{On}$ this issue, both Allen and Laudan and Risinger have offered competing positions, with Risinger having the better of the argument, at least for purposes of determining a current wrongful conviction rate figure. Our interest here is in determining a ratio of wrongful convictions obtained via trials versus guilty pleas. To estimate that figure, Allen and Laudan relied on Professor Brandon Garrett's 2008 article analyzing about 200 cases of DNA exonerations, in which $4.5 \%$ involved wrongful convictions resulting from guilty pleas. ${ }^{179}$ In his 2010 article, Risinger points out that the $4.5 \%$ figure Allen and Laudan used relied on older data, extending well before 2008, while in 2010 the percentage of exonerations involving those who had pled guilty collected in the National Registry of Exonerations had climbed to about

175. See supra note 131 and accompanying text.

176. See, e.g., John H. Blume \& Rebecca K. Helm, The Unexonerated: Factually Innocent Defendants Who Plead Guilty, 100 CoRnell L. ReV. 157 (2014).

177. See infra notes 213-20 and accompanying text.

178. See, e.g., Lucian E. Dervan \& Vanessa A. Edkins, Plea Bargaining's Innocence Problem, 103 J. CRIM. L. \& CRIMINOLOGY 1, 20-21 (2013); Blume \& Helm, supra note 176; Stephanos Bibas, Plea Bargaining's Role in Wrongful Convictions, in ExAMINING Wrongful Convictions: A Step Back, Moving Forward (Allison D. Redlich et al. eds. 2014); Alexandra Natapoff, Negotiating Accuracy: DNA in the Age of Plea Bargaining, in Wrongful Convictions AND THE DNA Revolution, supra note 12, at 85. See generally Robert E. Scott \& William J. Stuntz, Plea Bargaining as Contract, 103 Yale L.J. 1909, 1949-51 (1992).

179. See Allen \& Laudan, Deadly Dilemmas, supra note 49, at 71 n.41 (citing Brandon L. Garrett, Judging Innocence, 108 ColuM. L. REV. 55 (2008)). 
$7.5 \%{ }^{180}$ By November 2015, the registry showed an even higher figure-about $15 \%$ of their exonerations involved convictions via guilty pleas. ${ }^{181}$

Because the Registry contains a much bigger data set than the DNA exonerations reviewed by Garrett, it seems like a reasonable starting point for a general calculation. And it draws some additional validation from Risinger's remarkably prescient prediction back in 2010 that he thought the "real figure" for the percentage of wrongful convictions via guilty plea would be "two or three or four or more times higher" than $4.5 \% .{ }^{182}$ The Registry's current $17 \%$ figure falls within that projected range.

Any reasonable estimate of the ratio of wrongful convictions via guilty pleas versus trials will significantly drive down the overall wrongful conviction rate in the system if wrongful convictions via guilty pleas are rare. And good reasons exist for believing that the plea bargaining system produces a lower percentage of wrongful convictions than trials. ${ }^{183}$ Recent scholarship suggests that an "innocence effect" strongly reduces incentives for an innocent person to plead guilty. Professors Gazal-Ayal and Tor's 2012 article provides a good overview of the issue, ${ }^{184}$ collecting empirical evidence on the extent to which innocent people enter false guilty pleas. Gazal-Ayal and Tor conclude that "our evidence on the significant effect of innocence on plea behavior demonstrates that scholars' . . belief that plea bargains lead innocents routinely to make false guilty pleas is overstated." ${ }^{185}$ Based on empirical evidence, they found an innocence effect-i.e., "that plea bargainers are predominantly guilty, while innocents disproportionately refuse the plea and go

180. Risinger, supra note 61, at 996 n.20.

181. As of October 2016, the Registry reported that of 1,702 "exonerees," $17 \%$ pled guilty. See Gross, supra note 12, at 756; see also Innocents Who Plead Guilty, NAT'L REGISTRY EXONERATIONS (Nov. 24, 2015),

https://www.law.umich.edu/special/exoneration/Documents/NRE.Guilty.Plea.Article1.pdf.

Part of the reason for the recent increase appears to be many cases (133) from

Houston, Texas, in which defendants pled guilty to minor drug charges before lab results were received, and then the lab results later came back finding no illegal drugs. See Gross, supra note 12, at 776-77. Under the simple and inexorable calculus of the Registry, no drugs means no crime and, therefore, "factual innocence." See Glossary, supra note 66. But from a slightly broader perspective, most of these cases involved "bogus dope" where the defendant was trying to buy illegal drugs and got ripped off - according to Robert Wicoff, Harris County (Houston) Public Defender, in his private remarks at an innocence conference. See Anita Hassan \& Mike Tolson, Harris County Leads Way in 2014 Exonerations, Hous. CHRON. (Jan. 26, 2015), http://www.houstonchronicle.com/news/houston-texas/houston/article/HarrisCounty-leads-way-in-2014-exonerations-6041657.php. Such defendants are guilty of the crime of attempted purchase of illegal drugs, and thus whether they could be included in a compilation of "factually innocent" persons is dubious. I don't pursue the issue further here, because the effect of including these cases is to increase the wrongful conviction rate that this Article derives.

182. Risinger, supra note 61, at 995.

183. Id. at 996. But cf. Amos N. Guiora, Relearning the Lessons of History: Miranda and Counterterrorism, 71 LA. L. REV. 1147, 1174 (2011) (discussing pressures exerted on defendants by police outside formal trial procedures).

184. Oren Gazal-Ayal \& Avishalom Tor, The Innocence Effect, 62 DuKE L.J. 339 (2012).

185. Id. at 345 . 
to trial, which might result in their acquittal." 186 They also found that this innocence effect means that "plea bargains lead to beneficial, lower rates of wrongful convictions," 187 because it helps to reserve time- and resource-intensive trials for those who are more likely to be innocent. Similar suggestions are arguably found in recent "laboratory" studies of guilty pleas, ${ }^{188}$ although the extent to which the studies (involving Psychology 101 students threatened with "punishment," such as being reported to their teachers) are applicable to serious criminal proceedings is debatable.

To be sure, questions can be raised about whether exoneration data can fully capture the frequency with which innocent people plead guilty. ${ }^{189}$ For example, someone who has pled guilty may find it much more difficult to attract the attention of courts or others to prove innocence. In light of this concern, we might take the $17 \%$ figure and acknowledge that wrongful convictions in guilty-plea cases may still be underrepresented. We could simply increase the $17 \%$ figure to $20 \%$ to guard against the possibility of underrepresentation, which is the conservative approach I will take here.

\section{E. Calculating the Wrongful Conviction Rate through Component Parts with Current Data}

Recall that to determine a wrongful conviction rate figure through the component-parts methodology, three numbers are required: (1) a wrongful conviction rate at trial; (2) the ratio of wrongful convictions at trial versus via plea; and (3) the ratio of cases resolved via trial versus via plea. The previous two Sections have discussed the first two of the three figures. The last figure is not worth extended discussion, because fairly solid data is readily available on resolution of cases through trials and guilty pleas. A generally applicable trial-rate figure for all violent crimes is probably at least $95 \%,{ }^{190}$ although those charged with the violent crimes of murder and rape may be slightly less likely to plead guilty than the average felon. ${ }^{191}$

186. Id. at 394 .

187. $I d$.

188. See, e.g., Dervan \& Edkins, supra note 178 , at $34-35$ (89.2\% of guilty students accepted "plea" vs. $56.4 \%$ of innocent students).

189. Id. at 21.

190. See Lucian E. Dervan, Bargained Justice: Plea-Bargaining's Innocent Problem and the Brady Safety-Valve, 2012 UtAH L. REV. 51, 84 (more than 95\% guilty-plea rate); Brian Reaves, U.S. Dep't of Justice, Felony Defendants in Large Urban Counties, 2009-Statistical TABLES, at 24 tbl.21 (2013), https://www.bjs.gov/content/pub/pdf/fdluc09.pdf (of felony defendants, $66 \%$ convicted overall and $65 \%$ overall convicted via plea, suggesting a plea rate of around $98 \%(65 / 66)$ based on summing convicted via felony and misdemeanor pleas).

191. See Gross et al., supra note 54, at 536 n.30 (noting that $90 \%$ of those convicted of violent felony in large, urban counties in 1998 pled guilty). Recent data show guilty-plea rates of about $73 \%$ for murder, $90 \%$ for rape, $97 \%$ for robbery, $95 \%$ for assault, and $96 \%$ for other violent crimes. REAVES, supra note 190, at 24 tbl.21 (based on summing convicted via felony and misdemeanor pleas and dividing by total convicted). Given the predominance of assault and robbery crimes for the violent crime figure this Article attempts to calculate, a $95 \%$ plea rate seems a reasonable estimate. 
With the relevant figure in place, we are now able to calculate a wrongful conviction rate using the component-parts methodology as follows:

.0050 trial error rate

$\mathrm{X}$

20/80 ratio of wrongful convictions in guilty pleas versus trial

$\mathrm{X}$

$5 / 95$ overall ratio of trials to pleas

$=$

.000066 , or $0.0066 \%$, or 0.66 wrongful convictions out of 10,000 guilty pleas.

Then, using a weighted average to calculate the overall wrongful conviction rate-i.e., the $0.0066 \%$ wrongful conviction rate in guilty-plea cases and the $0.50 \%$ wrongful conviction rate in trials - leads to a wrongful conviction rate of $.00031,{ }^{192}$ or $0.031 \%$, or 3.1 out of 10,000 violent crime convictions. Of course, this wrongful conviction rate is not precise. To avoid any suggestion of false precision, the wrongful conviction rate might be stated as a range, running from $50 \%$ below to $100 \%$ above the $.031 \%$ rate-i.e., a wrongful conviction range of $0.016 \%$ to $0.062 \%$.

A host of caveats need to be attached to this range. As should be clear from the discussion above, precise data is lacking on many of the issues that are important in deriving the range. Perhaps the two key components are the two discussed at greatest length above: what percentage of violent crime cases occur under the conditions that might permit wrongful convictions ${ }^{193}$ and what is the ratio of wrongful convictions via guilty plea versus trial. ${ }^{194}$ These subjects need more thorough investigation before we can have firm confidence in the range. But lack of firm data has not prevented many other scholars from venturing an estimated wrongful conviction rate range. The range presented here rests on at least as firm a foundation as many others that have been presented.

While the implications of this range are discussed below, ${ }^{195}$ it is important to recognize that this range is far below the violent crime error rates conventionally discussed in the innocence literature. Taking, for example, Professor Gross's 2017 estimate of a violent felony wrongful conviction rate of about "one to several percent, ${ }^{, 196}$ this range is about two orders of magnitude lower. ${ }^{197}$ Indeed, this range is so low that, if correct, it could mean (in Professor Gross's words) that wrongful

192. $(.0000657 \times 95 / 5+.0050) /(100 \div 5)=.00031$. This is the same weightedaveraging formula used by Allen \& Lauden, Deadly Dilemmas, supra note 49, at 44, and not critiqued by Risinger or others, so far as I can determine.

193. See supra notes 73-121 and accompanying text.

194. See supra notes 178-91 and accompanying text.

195. See infra notes 243-47 and accompanying text.

196. Gross, supra note 12, at 785.

197. It is also significantly lower than Allen and Laudan's error rate of $0.84 \%$. See Allen \& Laudan, Deadly Dilemmas, supra note 49, at 71. 
convictions are "vanishingly rare" and "not . . much of a problem" 198 _ a point discussed later. ${ }^{199}$

\section{The Moral Culpability OF SOME OF The Wrongfully CONVICTED}

In addition to the quantitative points about wrongful convictions, one qualitative point deserves at least a brief mention. Typically, the cases highlighted by innocence scholars involve cases of completely innocent people who had no culpability whatsoever in producing their own wrongful convictions. But a high percentage of wrongful conviction cases involve prisoners who have previously committed many crimes. ${ }^{200}$ This point is suggested not only by the Yarris case discussed above, ${ }^{201}$ but also by a North Carolina case I worked on as an expert witness involving the alleged wrongful conviction of Robert Wilcoxson. ${ }^{202}$ The North Carolina Innocence Inquiry Commission found Wilcoxson to be innocent of a drug-related murder. ${ }^{203}$ But it appears that one reason he fell under suspicion was that, by his own admission, at the time of the murder he was an armed cocaine dealer making tens of thousands of dollars from his crimes. ${ }^{204}$ Four other adults also fell under suspicion and were also convicted, wrongfully they have apparently argued. ${ }^{205}$ Still, it appears that they may have all have been involved in a series of armed robberies at around the same time. ${ }^{206}$ Thus, in this one case from North Carolina, possibly involving multiple wrongful convictions, it appears that all five of the allegedly wrongfully convicted participants may well have been involved in other dangerous crimes apart from the murder for which they were convicted, which quite naturally made it harder for them to convince authorities of their innocence.

The Wilcoxson case is not an outlier. The available empirical research identifies a prior criminal record as a substantial contributing factor to wrongful conviction. Professor Findley, for example, has noted that "while wrongful conviction can happen to anyone, those with a prior record are at a significantly higher risk of suffering such an injustice; the rate of exoneration is almost 50 percent

198. Gross, supra note 1 , at 176.

199. See infra notes 224-48 and accompanying text.

200. See infra notes 208-11 and accompanying text.

201. Recall that Yarris was wrongfully convicted for a rape-murder he did not commit, but only after he tried to falsely implicate someone in the crime in an effort to be released from prison. See supra notes 89-99 and accompanying text.

202. I served as an expert witness on false confession issues for the law enforcement officers Wilcoxson sued, alleging deprivation of his constitutional rights.

203. State v Kagonyera, No. 00CRS56086, 2011 WL 8472667 (N.C. Super. Sep. $22,2011)$.

204. Deposition of Robert Wilcoxson, Wilcoxson v. Buncombe County et al., No. 1:13-cv-00224-MR-DLH (W.D.N.C. 2014) (on file with author).

205. See Robert P. Mosteller, N.C. Inquiry Commission's First Decade: Impressive Successes and Lessons Learned, 94 N.C. L. REV. 1725, 1730 n.1 (2016) (discussing innocence claims by Teddy Isbell, Damian Mills, and Larry Williams, Jr.).

206. Testimony of Damian Mills to North Carolina Innocence Inquiry Commission, at 481-82 (Dec. 18, 2013) (stating that he had been doing a series of breaking-and-entering crimes with Kagonyera, Williams, Isbell, and Brewton). 
higher for those with a criminal record than for those without." ${ }^{207}$ Findley's suspicions are supported by data from the National Registry of Exonerations. In a recent preliminary tabulation (in 2017) when the Registry had collected 2,101 exonerations - and a total of 1,536 cases with reported data on prior records - of those with prior-record data, $647(42 \%)$ had a prior felony conviction, $163(11 \%)$ had a prior misdemeanor conviction, $30(2 \%)$ had a prior juvenile felony conviction, and $13(1 \%)$ had a prior juvenile misdemeanor conviction. ${ }^{208}$ These numbers may be slightly on the low side because it is possible that the data collected missed some prior crimes known to police, ${ }^{209}$ and it may be easier for a person without a prior conviction to obtain an exoneration (and thus a listing in the Registry) than one with such a conviction. But the general picture of significant prior criminal activity by the wrongfully convicted is clear. And more broadly, it is also true that in the modern era, most defendants who stand trial have a criminal record that predates the charged crime. $^{210}$

A related point can be made about the wrongfully convicted who have pled guilty. Unless the defendant has entered an Alford plea (pleading guilty but preserving his position of innocence ${ }^{211}$ ), he has almost certainly committed perjury before the Court in entering his plea. Again, this point can be made by looking at the Wilcoxson case from North Carolina, just discussed. ${ }^{212}$ At their guilty-plea

207. Keith A. Findley, Reducing Error in the Criminal Justice System, 48 SETON Hall L. Rev. 1265, 1301 (2018); see also Jon B. Gould et al., Predicting Erroneous Convictions, 99 IowA L. REv. 471, 492 (2014) (finding that prior criminal history influences case outcome in wrongful conviction cases).

208. Email from Samuel Gross, Professor Emeritus, Univ. of Mich. Law Sch. to author (Sept. 30, 2017) (on file with author) (preliminary tabulation of data for National Registry of Exonerations). These numbers are for the highest prior in each category-i.e., a person with a felony conviction may also have misdemeanor convictions.

209. See id. (noting this limitation but estimating that the difference might be in the range of an additional $1 \%-2 \%$ ).

210. Jeffrey Bellin, The Silence Penalty, 103 Iowa L. REv. 395, 398 (2017) (citing REAVES, supra note 191, at 8, 10-11 (reporting that $75 \%$ of suspects charged with a felony had a prior arrest; $60 \%$ had a prior felony arrest; $60 \%$ had at least one prior conviction; and $43 \%$ had at least one prior felony conviction)); Theodore Eisenberg \& Valerie P. Hans, Taking a Stand on Taking the Stand: The Effect of a Prior Criminal Record on the Decision to Testify and Trial Outcomes, 94 CoRnell L. ReV. 1353, 1371 tbl.1 (2009) (study of felony trials in four jurisdictions found $76 \%$ of the defendants standing trial had some kind of criminal record); Martha A. Myers, Rule Departures and Making Law: Juries and Their Verdicts, 13 LAW \& SOC'Y REV. 781, 786-90, 786 tbl.1 (1979) (not reporting percentage but instead providing statistic of an average of 2.7 prior convictions per defendant and that "most defendants had prior convictions"); see also HARRY KALVEN, JR. \& HANS ZEISEL, THE AMERICAN JURY 33 n.1 \& 145 (2d ed. 1971) (in 47\% of the trials in their sample from 1954 to 1955 , the defendant had a prior record).

211. See generally Stephanos Bibas, Harmonizing Substantive Criminal Law Values \& Criminal Procedure: The Case of Alford \& Nolo Contendere Pleas, 88 ConNell L. REV. 1361 (2003); Josh Bowers, Punishing the Innocent, 156 U. PA. L. REV. 1117, 1165-72 (2008); Sydney Schneider, Comment, When Innocent Defendants Falsely Confess: Analyzing the Ramifications of Entering Alford Pleas in the Context of the Burgeoning Innocence Movement, 103 J. CRIM. L. \& CRIMINOLOGY 279 (2013).

212. See generally State v. Kagonyera/Wilcoxson, N.C. INNOCENCE INQUIRY COMMISSION, http://innocencecommission-nc.gov/cases/state-v-kagonyera-wilcoxson/ (last 
hearings, both Wilcoxson and a codefendant, Kenneth Kagonyera, swore under oath that they were guilty, that they were satisfied with defense counsel, and that the other requisites for a knowing and voluntary guilty plea existed. ${ }^{213}$ So far as the court records reveal, they also made no effort to enter an Alford plea. In addition, after Kagonyera pled guilty, he met with the prosecutor and, in the presence of defense counsel, made a very detailed statement about his involvement in the murder, implicating five other people. ${ }^{214}$ Kagonyera made these statements at his own initiative in an effort to convince the District Attorney that he could provide useful information by testifying against his codefendants. ${ }^{215}$

To be clear, if Kagonyera and Wilcoxson were in fact innocent, ${ }^{216}$ their guilty pleas were plainly wrongful convictions. And no doubt, their pleas resulted from a plea bargaining process that can be coercive and place considerable pressure on even innocent people to plead guilty - making the choice of an innocent person to plead guilty in some sense rational. ${ }^{217}$ But particularly where defendants (like Kagonyera and Wilcoxson) have made no effort to enter Alford pleas, ${ }^{218}$ a decision to mislead the Court and enter a guilty plea produces a wrongful conviction that is, at least to some extent, the result of illegal choices on their part and presumably entitled to somewhat less weight in any social-harm calculus. ${ }^{219}$

The point here is not to blame those wrongfully convicted for their plight. The more limited argument is that, when assessing the priority to be given to competing claims between those wrongfully convicted and those who are past (or prospective) crime victims, the victims may have far stronger claims. Some support for this position comes from a study reporting that, for homicide and assault cases, most of the victims had no prior arrest record, while most offenders did. ${ }^{220}$ This suggests that simply weighing the risk of being a victim of a violent crime versus

visited Sep. 13, 2018).

213. See State v. Kagonyera, Nos. 00 CRS 65086, 00 CRS 65088, 2011 WL 8472666 (N.C. Super. Ct. Apr. 29, 2011).

214. N.C. Innocence Comm'n Brief at 101, State v. Kagonyera, Nos. 00 CRS 65086, 00 CRS 65088 (N.C. Super. Ct.) (Memo. from Investigator Raymond to D.A. Moore regarding statement made by Kenneth Kagonyera (Nov. 30, 2001)), http://innocencecommission-nc.gov/wp-content/uploads/state-v-kagonyera-wilcoxson/statev-kagonyera-wilcoxson-brief.pdf .

215. Transcript of Kagonyera Deposition at 134-35, State v. Kagonyera (Jan. 9, 2015) (Nos. 00 CRS 65086, 00 CRS 65088), http://innocencecommission-nc.gov/wpcontent/uploads/state-v-kagonyera-wilcoxson/transcript-of-kagonyera-deposition.pdf (admitting this fact).

216. The North Carolina Innocence Inquiry Commission found both men to be factually innocent. See generally State v. Kagonyera / Wilcoxson, supra note 213.

217. Compare Bowers, supra note 211, at 1165-72 (arguing that even Alford pleas are invariably coercive), with Stephanos Bibas, Exacerbating Injustice, 157 U. PA. L. Rev. PENNUMBRA 53, 54 (2008) (responding to Bowers' article).

218. Currently about 47 states, the District of Columbia, and the federal system allow Alford pleas. See Bibas, supra note 211, at 1372 n.52.

219. It is also possible that they choose to plead guilty to the murder because they were guilty of other serious, violent crimes. See supra note 207 and accompanying text.

220. See Varnedoe, supra note 108, at 8-9. 
the risk of being wrongfully convicted (as done in the next Section of this Article) may not fully capture the competing weights on different sides of the scale.

To be sure, it is also possible to argue that a wrongful conviction may have greater harmful consequences than does being the victim of a violent crime. While the argument is difficult to make for the violent crime of murder, it is quite plausible for the violent crime of aggravated assault. And, in theory at least, it should be possible to try to quantify the size of competing concerns ${ }^{221}$ —although significant practical problems exist in trying to attach precise metrics. Criminal victimization and wrongful conviction can both cause tremendous suffering. ${ }^{222}$ But tracing out precise weights for competing sides of the scale is a project for a different article. This Article simply notes that, when discussing cases of wrongful conviction, a significant percentage of the defendants may bear some moral culpability for having been wrongfully convicted.

\section{Placing the Wrongful Conviction Rate in Context}

We now have an estimated concrete, empirically grounded wrongful conviction rate range: $0.016 \%-0.062 \% .{ }^{223}$ This range provides some tentative measure of the wrongful conviction rate for violent crimes. And we also have some sense that at least some of the wrongfully convicted will bear some degree of moral culpability for their plight. All these points are, of course, subject to debate. But in this concluding Part, it is worth considering the implications if these findings are correct and, in particular, whether such a low frequency of wrongful convictions would mean, in Professor Gross's words, they are "not ... much of a problem." 224

While the range is a low one, I reach a slightly different conclusion than Gross. While the lower range suggests that innocence scholars have (perhaps unsurprisingly) overstated the magnitude of the problem they are investigating, innocence issues should remain a subject of concern. The lower range also suggests, however, that innocence reform measures that increase the risk of guilty people escaping conviction may be hard to justify through cost-benefit analysis. This concern only increases the need to search for innocence reforms that avoid such tradeoffs.

\section{A. The "Low" Risk of Wrongful Conviction}

How low is the estimated wrongful conviction rate range of $0.016 \%$ $0.062 \%$ ? It is useful to note initially that the range comfortably embraces the oftencriticized $0.027 \%$ figure cited by Justice Scalia in Kansas v. Marsh. ${ }^{225}$ Perhaps

221. See Paul G. Cassell, Tradeoffs Between Wrongful Convictions and Wrongful Acquittals: Analyzing the Risks and Avoiding the Risks, 48 SEton Hall L. Rev. 1435, 144546 (2018); see also Shima Baradaran Baughman, Costs of Pretrial Detention, 97 B.U. L. REV. 1, 9 (2017) (discussing quantification of the costs of crime); BRIAN FORST, ERRORS OF Justice: NATURe, SourCes AND Remedies 45-56 (2004) (same).

222. See, e.g., Paul G. Cassell, In Defense of Victim Impact Statements, 6 Оніо ST. J. CRIM. L. 611, 629-30 (2009) (collecting examples of victim impact statements).

223. See supra Section II.E.

224. Gross, supra note 1, at 176.

225. Kansas v. Marsh, 548 U.S. 163, 198 (2006) (Scalia, J., concurring) (citing Joshua Marquis, The Innocent and the Shammed, N.Y. TIMES, Jan. 26, 2006, at A23). 
because Scalia's calculation was such an approximation, ${ }^{226}$ the innocence movement did not feel the need to seriously consider its implications. Thus, Professor Gross could casually assert that such a low overall error rate would mean that false confessions were "vanishingly rare" and would demonstrate that "they would not be much of a problem." 227 And others like Professor Dan Simon could quickly agree that a wrongful conviction rate of $0.027 \%$ would be "indeed a small number," 228 while Professor Risinger could conclude that, if true, such a figure "would be cause for rejoicing ...."229

But it is worth working through the implications of such a low error rate more carefully than past commentators have done. One way to provide some context is by considering how many people are wrongfully convicted for violent crimes if this Article's error-range figures are correct. Such an extrapolation is a standard approach in the innocence literature. ${ }^{230}$ Taking the midpoint of the range $(0.031 \%)$ and applying it across the number of arrests for violent crimes (according to the FBI Uniform Crime Reports) produces the result of about 160 people wrongfully convicted each year in this country for a serious violent crime. ${ }^{231}$ This a conservative calculation-i.e., it provides a generous figure-because the more accurate multiplication would not be across arrests, but rather across the smaller number of convictions.

Whether 160 is a number worth worrying about depends on your perspective. Of course, for the 160 people involved - and their friends and families - that is a large number. On the other hand, some might compare it to other risks in our sprawling country to argue it is insignificant. I take this to be the point of Professor Gross's suggestion that a number of this size would not be much of a problem. And someone intent on arguing that this is a small number could point out that, by this estimate, about twice as many people are struck by lightning each year as are wrongfully convicted for violent crimes. ${ }^{232}$

Another way to provide some context to the wrongful conviction error-rate figure is to compare the risk of a wrongful conviction with other risks, particularly risks connected to the way in which the criminal justice system operates. One comparison that immediately comes to mind is the risk of being wrongfully

226. Sam Gross has persuasively critiqued the methodology used by Marquis to arrive at this calculation as relying upon a denominator that is too big. See Gross, supra note 5, at 69-70. The component-parts error rate avoids this particular problem.

227. Gross, supra note 1, at 176

228. Dan Simon, In Doubt: The Psychology of the Criminal Justice Process 226 n. 12 (2012).

229. Risinger, supra note 53, at 762.

230. See, e.g., Zalman, supra note 6, at 277-78.

231. In 2016, there were 515,151 arrests for violent crimes. See Table 18: Estimated Number of Arrests, FBI: UNIFORM CRIME REP. 2016, https:/ucr.fbi.gov/crime-in-theu.s/2016/crime-in-the-u.s.-2016/topic-pages/tables/table-18 (last visited Oct. 18, 2018). $515,151 \times 0.031 \% \approx 160$.

232. See Occupational Safety \& Health Admin., Fact Sheet: Lightning SAFETY WHEN WORKING OUTDOORS 1 (2016), https://www.weather.gov/media/owlie/OSHA_FS-3863_Lightning_Safety_05-2016.pdf (300 people struck by lightning in the United States annually). 
convicted compared to the risk of becoming the victim of a violent crime. Using the figures derived above, it is possible to provide a comparison of these two risks, as has been done in the literature before. ${ }^{233}$ Previous research suggests that the probability that someone will serve time in state or federal prison during his or her lifetime is approximately $6.6 \%$, and about one-third of these commitments-i.e., $2.2 \%$ - are for violent crimes. ${ }^{234}$ Accordingly, it is possible to calculate a lifetime risk that someone will be sent to prison as the result of a wrongful conviction for a violent crime by multiplying the wrongful conviction risk by the sent-to-prison-forviolent-crime risk of $2.2 \%$. Using the wrongful conviction figures above, the lifetime risk is $.00000682,{ }^{235}$ or $0.00068 \%$, or 0.68 out of every 100,000 people.

What about the risk of being the victim of a violent crime? Here, matters are somewhat simpler to calculate. A 1987 U.S. Justice Department report based on crime-victimization data offers a calculation of lifetime victimization risks. ${ }^{236}$ The report concluded that the lifetime risk of being a victim of a violent crime was $83 \%$ and of being a victim of a robbery or an assault resulting in injury was $40 \% .{ }^{237}$ Unfortunately, that report has apparently not been updated. It was published in 1987 based on National Crime Survey data from 1975 to 1984. Since then, victimization rates have fallen substantially by around $50 \%{ }^{238}$ Accordingly, in order to have a current victimization figure comparable to the current wrongful conviction figure calculated above, it is necessary to lower the lifetime figure to reflect this fact. Adjusting for lower current crime rates, the current lifetime probability that a person will be a victim of a violent crime is probably about $41.5 \%$ and that a person will be a victim of a robbery or assault resulting in injury about $20 \% .{ }^{239}$

233. See Allen \& Laudan, Deadly Dilemmas, supra note 49, at 80.

234. Id. at $80 \mathrm{n} .81$ (citing Thomas P. Bonczar, U.S. DeP'T of Justice, PREVAlENCE OF IMPRISONMENT IN THE U.S. PoPUlATION, 1974-2001 (2003)). Bonczar's 2003 study does not break out the percentage of admissions to violent crimes, but his earlier study based on 1991 data showed that $32.8 \%$ of the admissions were for violent offenses. THOMAS P. Bonczar \& Allen J. Beck, U.S. Dep't of Justice, Lifetime Likelihood of Going to STATE OR FEDERAL PRISON 5 (1997), https://bjs.gov/content/pub/pdf/Llgsfp.pdf. More recent data appears to show that violent offenses constitute fewer than one-third of admissions to prison. See Sean Rosenmerkel et al., U.S. Dep't of Justice, Felony Sentences in State COURTS, $2006-$ STATISTICAL TABLES 5 tbl.1.2.1 (2010), https://www.bjs.gov/content/pub/pdf/fssc06st.pdf. For simplicity and to be conservative, I use Allen and Laudan's one-third figure. Allen and Laudan also highlight rape cases, while I have calculated figures for all violent crimes.

235. $.00031 \times .022=.00000682$.

236. Herbert Koppel, U.S. Dep'T of Justice, Technical Report: Lifetime LiKELIHOOD OF ViCTIMIZATION 2 tbl.1 (1987), https://www.bjs.gov/content/pub/pdf/llv.pdf (discussed in Allen \& Laudan, Deadly Dilemmas, supra note 49, at 80 n.81).

237. Id.

238. See generally BARry LATZER, The Rise and FAll of Violent CRime in America 221-64 (2016); Franklin E. Zimring, The Great American Crime Decline 324 (2007).

239. Making an exact adjustment for lower current crime rates is difficult, because the lifetime victimization numbers rest on a nine-year (1975 to 1984) aggregation. Moreover, it appears that recent adjustments have been made to the methodology for collecting victimization data, which may make direct comparisons difficult. See, e.g., RACHEL MORGAN \& Grace Kena, U.S. Dep't of Justice, Criminal Victimization, 2016, at 2 (Dec. 2017), 
With these numbers in mind, it is possible to compare the relative risks of these two events-i.e., compare the risk that a person will be the victim of a violent crime versus the risk that they will be wrongfully convicted and sent to prison for a violent crime. Indeed, in their earlier article, Professors Allen and Laudan attempted such a comparison, concluding that "we can say with considerable confidence, that the [lifetime] risk of being the victim of a serious crime in the United States is significantly more than 300 times greater than the lifetime risk of being falsely convicted of a serious crime." ${ }^{240}$ However, their comparison simply began by accepting Risinger's 3.3\% trial error rate - an error rate that, as discussed above, is too high. Substituting the more realistic error rate calculated here, the approximate risk ratios suggest that a person is about 30,000 times more likely to be the victim of a violent crime than to be wrongfully convicted and sent to prison for a violent crime and about 15,000 times more likely to be the victim of a robbery or assault resulting in injury than to be wrongfully convicted and sent to prison for a violent crime. ${ }^{241}$

\section{B. Ensuring that Innocence Reforms Do Not Block Prosecution of the Guilty}

From comparisons such as these, it is possible to conclude that wrongful convictions are "vanishingly rare" and "not ... much of a problem." I draw a slightly different and more nuanced conclusion. An error rate of $0.031 \%$ does show a remarkably high degree of accuracy in America's criminal justice system. But the goal of the system, of course, should always be $100.000 \%$ accuracy. If there are steps that can reasonably be taken to drive down what is already a very low error rate even further, those steps should be taken.

Where this quantification becomes important, however, is in considering possible tradeoffs that inhere in certain innocence reforms. Sadly, wrongful convictions are not the only kinds of tragedies that the criminal justice system must be concerned about. ${ }^{242}$ As Josh Marquis has cogently observed, "The justice system is far from perfect and has made many mistakes, mostly in favor of the accused. Hundreds, if not thousands, have died or lost their livelihoods through embezzlement or rape because the American justice system failed to incarcerate people who were guilty by any definition." 243

Certain reforms to the system pose no risks of tradeoffs at all. For example, DNA technology made it possible to more precisely identify markers left at crime

https://www.bjs.gov/content/pub/pdf/cv16.pdf. As best I can determine, the most recent (2016) violent crime victimization rate is 24.2 per 1,000 population, see $i d$., which is at least $50 \%$ of the rate reported during the 1975-1984 period. Accordingly, to come up with a conservative calculation, I simply cut the 1987 BJS lifetime victimization numbers in halfi.e., multiplied by .5 - to have them roughly reflect current crime victimization rates.

240. Allen \& Laudan, Deadly Dilemmas, supra note 49, at 79-80.

241. Taking $41.5 \%$ and $20.0 \%$ and dividing by $.0011 \%$, produces ratios of more than 37,000:1 and 18,000:1 respectively. It is possible that these ratios are slightly overstated, because it is not clear that the definition of "violent crime" corresponds precisely in the two lifetime-risk ratios. To guard against this possibility, I have reduced the risk ratio slightly to the numbers shown in the text.

242. See Alec Whalen, Proof Beyond a Reasonable Doubt: A Balanced Retributive Account, 76 LA. L. REV. 356, 357-60 (2015).

243. Marquis, supra note 17, at 517-18 (emphasis added). 
scenes, thus not only helping to convict the guilty but to exclude the innocent from erroneously falling under suspicion. And in other articles, I have tried to expand this point, identifying other reforms in the criminal justice system that could provide greater protection against wrongful convictions while posing no obstacle to conviction of the guilty. ${ }^{244}$ For example, we could expand research aimed at quantifying the magnitude and scope of the wrongful conviction problem and how we might respond to it. ${ }^{245}$ "Win-win" approaches of this type should be readily embraced.

But in structuring our criminal justice system, all too often hard choices have to be made between providing protections against wrongful convictions and protections for society by allowing the criminal justice system to move forward even at the risk of an occasional error. ${ }^{246}$ For example, more rigid requirements for a valid eyewitness identification may protect some innocent people from being mistakenly identified, but at the cost of preventing some guilty people from being properly identified. ${ }^{247}$ In assessing the tradeoffs involved in such reforms, the size of relative risks does matter. And it is in such assessments that the quantification attempted in this Article will be important. If we are weighing competing risks, it would be one thing to know that the current criminal justice system is wrongfully convicting 3\% of all people who are charged - and quite another to know that the system makes such errors in $0.031 \%$ of all cases. Where the cost-benefit calculation tips will depend on the particulars of each situation. But it is important to have some realistic assessment of how well the system is functioning.

\section{CONCLUSION}

This Article attempts a preliminary answer to the most basic and important question about wrongful convictions: how often do they occur? While previous scholars have suggested that the general wrongful conviction rate is at least $1 \%$ - or

244. See, e.g., Paul G. Cassell, Can We Protect the Innocent without Freeing the Guilty? Thoughts on Innocence Reforms that Avoid Harmful Trade-offs, in WRONGFUL Convictions AND the DNA Revolution, supra note 12, at 264; see also Carissa Byrne Hessick, DNA Exonerations and the Elusive Promise of Criminal Justice Reform, 15 OнIо ST. J. CRIM. L. 271, 277 (2017).

245. Cassell, supra note 244, at 271-72.

246. See Paul G. Cassell, Freeing the Guilty Without Protecting the Innocent: Some Skeptical Observations on Proposed New "Innocence" Procedures, 56 N.Y. L. ScH. L. REv. 1063,1078-80 (2011); $c f$. Henrik Lando \& Murat C. Mungan, The Effect of Type-1 Error on Deterrence, 53 INT'L REV. L. \& ECON. 1 (2018) (arguing that wrongful convictions do not generally lead to the tradeoff of lower deterrence). See generally Matthew Tokson, Blank Slates, 59 B.C. L. REV. 591, 608 (2018) (discussing approaches to normative balancing).

247. See generally Steven E. Clark, Blackstone and the Balance of Eyewitness Identification Evidence, 74 ALBANY L. REV. 1105 (2010) (discussing tradeoffs); Laurie N. Feldman, The Unreliable Cases Against the Reliability of Eyewitness Identifications: A Response to Judge Alex Kozinski, 34 QuinNiPIAC L. REV. 493 (2016) (same); see also Athan P. Papailious, David V. Yokum \& Christopher T. Robertson, The Novel New Jersey Eyewitness Instruction Induces Skepticism But Not Sensitivity, PLOS-ONE, Dec. 9, 2015, http://journals.plos.org/plosone/article?id=10.1371/journal.pone.0142695 (finding that recently adopted New Jersey cautionary instruction caused mock jurors to indiscriminantly discount "weak" and "strong" testimony in equal measure). 
$4 \%$ or even more - this Article reaches a quite different conclusion. Based on current data, it is possible to construct a plausible error rate for violent crimes somewhere in the range of $0.016 \%-0.062 \%$.

In deriving this estimate, I have tried to "show my work"-i.e., to lay out all the assumptions that are required and the specific empirical foundation that underlies each of them. Of course, it would be desirable to have more data about the many subjects discussed here. This Article has highlighted many areas where research is lacking and has called for efforts to more accurately map the landscape. Perhaps my reassessment and reduction of earlier estimates will spur further research on this important subject.

This Article does not claim to be the last word on the subject of America's wrongful conviction rate. Without a doubt, improvements can and will be made to the estimates advanced here. But the important, big-picture point from this estimate is that the innocence literature has apparently been assuming wrongful conviction rates that seem to be well above the real-world mark. America's criminal justice system is imperfect. But at least on this measure, it is not nearly so bad as many others have suggested. 


\section{APPENDIX - ANALYSIS OF RISINGER's WRONGFUl CONVICTION CASES IN LIGHT OF CONTEMPORARY STANDARDS}

This Appendix analyzes the 11 cases of wrongful conviction that form the basis for Professor Michael Risinger's 3.3\% wrongful conviction rate. ${ }^{248}$ The 11 cases were tried between 1982 and 1989. ${ }^{249}$ The limited point of this Appendix is that, in each of the 11 cases, due to improvements in DNA testing and forensic sciences, as well as other new legal safeguards against wrongful conviction, none of these wrongfully convicted people ${ }^{250}$ would be convicted if the trial had been held today.

The 11 cases are discussed in chronological order of the date of trial.

\section{A. Nicholas Yarris (1982)}

In 1982, Nicholas Yarris was convicted and sentenced to death for abduction, rape, and murder in Pennsylvania. ${ }^{251}$ Yarris was pulled over, driving a stolen car, ${ }^{252}$ four days after the victim's body was found. ${ }^{253} \mathrm{He}$ then attacked the police officer and was arrested for attempted murder. ${ }^{254}$ While in custody, Yarris confessed that he and a friend abducted the victim and that Yarris raped her and his friend stabbed her to death. ${ }^{255}$ This, combined with the facts that Yarris visited the victim's place of employment after she was killed, ${ }^{256}$ a jailhouse informant claimed Yarris confessed to him, and Yarris's bodily fluids seemingly matched that of the perpetrator, ${ }^{257}$ led to his conviction and death sentence in $1982 .{ }^{258}$

In 1984, Yarris escaped custody. ${ }^{259} \mathrm{He}$ was caught and convicted for the escape and stealing the car which set off the events of his initial arrest but was acquitted of attempted murder of the police officer who pulled him over. ${ }^{260}$

As discussed above, ${ }^{261}$ conventional serological testing was performed on the rape kit, the results of which could not exclude Yarris. In 2003, Yarris was

248. See Risinger, supra note 53, at 780.

249. See id. at 770-71, 770 n.14.

250. For simplicity, I assume all 11 cases involve factually innocent people who were wrongfully convicted.

251. Nicholas Yarris, supra note 90.

252. Death Penalty: Nicholas Yarris Spent 22 Years on Death Row for a Murder He Didn't Commit, Times Herald (Sept. 12, 2015, 8:36 PM), https://www.timesherald.com/news/death-penalty-nicholas-yarris-spent-years-on-deathrow-for/article_9967bc39-4c07-51b8-b377-b39c38e50eee.html.

253. Nicholas Yarris, supra note 90.

254. Id.

255. Commonwealth v. Yarris, 549 A.2d 513, 520 (Pa. 1988).

256. Yarris said to one of the victim's coworkers, "I heard that she was raped." At that time, the rape was not public knowledge. $I d$. at 584 .

257. The perpetrator had type $\mathrm{AB}$ or $\mathrm{B}$ secretions, which constituted $13 \%$ of the male population, and Yarris was type B. Id. at 583.

258. Nicholas Yarris, supra note 90.

259. Death Penalty: Nicholas Yarris Spent 22 Years on Death Row for a Murder He Didn't Commit, supra note 252.

260. Id. Yarris claims the charges of attempted murder were "trumped up."

261. See supra note 94 and accompanying text. 
exonerated after DNA evidence definitively ruled him out as the perpetrator of the crime. ${ }^{262}$

\section{B. Charles Fain (1983)}

Charles Irvin Fain was convicted of the kidnapping, sexual assault, and murder of a nine-year-old girl in Idaho. ${ }^{263} \mathrm{He}$ was arrested nearly one year after the murder when an eyewitness described a car similar to Fain's "uniquely painted automobile" in the vicinity of the abduction and the abductor as having similar features to Fain. ${ }^{264}$ Pubic hairs found on the victim's body were similar to Fain's, and jailhouse informants claimed Fain confessed to the crime. ${ }^{265}$ Further, Fain allegedly asked a friend, "What would you say if I told you I killed someone?" and a shoeprint near the body could have been made by one of Fain's shoes. ${ }^{266}$ However, Fain passed a polygraph test, which indicated he was not the perpetrator; he claimed he was asleep at his father's house in Oregon, 360 miles away. ${ }^{267}$

As discussed earlier, the hair-fiber evidence would presumably be treated more favorably to Fain today in light of recent advances in forensic science in the area. ${ }^{268}$ More significantly, in 2001 mitochondrial-DNA testing definitively ruled him out as the perpetrator. ${ }^{269}$ As Fain's attorney explained after the DNA tests, "The hair was really the linchpin of [the prosecution's] case, and the other evidence is highly suspect. It is not just that the state has the same case minus the hair evidence; the pubic hair evidence is now our evidence. It is exonerating evidence." ${ }^{270}$

\section{Earl Washington (1984)}

Earl Washington, Jr. was convicted and sentenced to death for rape and murder in 1984 in Virginia. ${ }^{271}$ Washington, who had an IQ of $69,{ }^{272}$ came under suspicion after he was arrested, nearly one year after the murder, for "breaking into

262. Nicholas Yarris, supra note 90; see also Cacciottolo, supra note 140 (noting "there were DNA traces of two unknown men in the car and on [the victim's] clothing").

263. Charles Fain, NAT'L REGISTRY EXONERATIONS,
https://www.law.umich.edu/special/exoneration/Pages/casedetail.aspx?caseid=3209 (last visited Oct. 4, 2018).

264. State v. Fain, 774 P.2d 252, 225 (Idaho 1989).

265. Charles Fain, supra note 263. One of the informants later recanted his testimony and claimed that prosecutors threatened him to get him to testify. Henry Weinstein, Condemned Man Could Go Free After DNA Testing, L.A. TIMES (Aug. 19, 2001), http://articles.latimes.com/2001/aug/19/news/mn-35886.

266. Fain, 774 P.2d at 255.

267. Raymond Bonner, Death Row Inmate Is Freed After DNA Test Clears Him, N.Y. Times (Aug. 24, 2001), http://www.nytimes.com/2001/08/24/us/death-row-inmate-isfreed-after-dna-test-clears-him.html.

268. See supra notes 132-34 and accompanying text.

269. Bonner, supra note 267. The trial judge told the New York Times, "If I had the slightest doubt, I certainly would not have imposed the death penalty." Id.

270. Weinstein, supra note 265.

271. Earl Washington, INNOCENCE PROJECT, https://www.innocenceproject.org/cases/earl-washington/ (last visited Sep. 13, 2018). See generally Margaret EdDS, An Expendable Man: The Near-Execution of EARL WASHINGTON, JR. (2003).

272. $\quad$ Earl Washington, supra note 271 
the apartment of an elderly neighbor and beating her with a chair. He also stole a gun from the victim, which he subsequently used to shoot his brother in a dispute over a woman." 273

When in custody, Washington confessed to five crimes, "the first four were dismissed by the Commonwealth because of the inconsistencies of the testimony and the inability of the victims to identify Washington." 274 His answers to questions regarding the rape and murder were drastically different from the facts of the case.

Evidence found at the crime scene included "a rare plasma protein," which Washington did not possess. ${ }^{275}$ After he became a suspect, "an amended forensic report was prepared (without additional testing being conducted) that said testing for the rare protein was "inconclusive." ${ }^{276}$ In 1993, "DNA test results revealed that Washington was excluded as a contributor of the seminal stain," but he was unable to introduce new evidence under Virginia law, and instead his death sentence was commuted to life in prison. ${ }^{277}$ In 2000 , the DNA test prompted the governor of Virginia to release Washington from prison and give him a limited pardon in $2001 .^{278}$ Six years later, in 2007, Washington was given an absolute pardon after another inmate already serving life in prison for rape pled guilty to the rape and murder. 279

\section{Kirk Bloodsworth (1985)}

Kirk Bloodsworth was sentenced to death in 1985 for the rape and murder of a nine-year-old girl in Maryland. ${ }^{280}$ Evidence used at trial included five witnesses who testified that he was with the victim or near the scene of the crime when it was committed and shoe marks on the victim's body that were linked to a pair of Bloodsworth's shoes. ${ }^{281}$

In 1993, Bloodsworth became "the first U.S. death row prisoner to be cleared by DNA" and was given "a full pardon based on innocence" the following year. ${ }^{282}$ In 2003, newly found stains on a sheet from the crime were tested for DNA. The DNA matched that of Kimberly Shay Ruffner, who had been in the same prison

273. Washington v. Wilmore, 407 F.3d 274, 276 (4th Cir. 2005).

274. Earl Washington, supra note 271.

275. Id.

276. $I d$.

277. Id.

278. Id.

279. Id.

280. See Tim Junkin, Bloodsworth: The True Story of the First Death Row INMATE EXonerated By DNA Evidence 4 (2005); BARry SCHECK ET. AL, ACTUAL InNocence: When Justice Goes Wrong And How to Make It Right 275-88 (2003).

281. Kirk Bloodsworth, NAT'L REGISTRY EXONERATIONS, https://www.law.umich.edu/special/exoneration/Pages/casedetail.aspx?caseid=3032 (last visited Oct. 4, 2018). Two of the witnesses could not identify Bloodsworth in a lineup "but had seen him... on television." Kirk Bloodsworth, InNOCENCE PROJECT, https://www.innocenceproject.org/cases/kirk-bloodsworth/ (last visited Oct. 4, 2018).

282. Kirk Bloodsworth, NAT'L REGISTRY EXONERATIONS, supra note 281. 
with Bloodsworth; Bloodsworth, as the prison librarian, "had regularly delivered books to Ruffner and the two had lifted weights together."283

\section{E. Rolando Cruz (1985)}

Rolando Cruz was convicted and sentenced to death for the 1983 kidnapping, rape, and murder of a ten-year-old girl in Illinois. ${ }^{284}$ Cruz was "a 20year-old gang member who gave the police a fabricated story in the hope of collecting [a \$10,000] reward." 285 Instead, it caused Cruz and two of his associates, Alejandro Hernandez (discussed below) and Stephen Buckley, to come under suspicion, and all three were charged with the kidnapping, murder, and rapeamong other crimes. ${ }^{286}$

Despite Cruz's dubious actions, John Sam, the lead detective on the case, "resigned in protest, because he believed the three men were innocent." ${ }^{287}$ Cruz and Hernandez were convicted and sentenced to death. ${ }^{288}$ After the trial, "a serial killer named Brian Dugan confessed that he alone had committed the crime," and the convictions were reversed in $1989 .{ }^{289}$ Cruz and Hernandez were retried, and Cruz was once again convicted and sentenced to death. ${ }^{290}$ Eventually, DNA evidence conclusively excluded both Hernandez and Cruz and established that Brian Dugan had in fact committed the rape and murder. ${ }^{291}$

\section{F. Alejandro Hernandez (1985)}

As just discussed in connection with Rolando Cruz, Alejandro Hernandez fell under suspicion for the kidnapping, rape, and murder of a 10-year-old girl when his associate, Rolando Cruz, lied about having information on the case in order to get the $\$ 10,000$ reward offered. ${ }^{292}$ Both Hernandez and Cruz were convicted of the crime. Eventually, DNA conclusively ruled out both men and established that the serial killer who had confessed years earlier had indeed committed the crimes. ${ }^{293}$

\section{G. Verneal Jimerson (1985)}

Verneal Jimerson, along with three other men-collectively known as the "Ford Heights Four" "294_ — was convicted and sentenced to death for the murder of a

283. Id.

284. Rolando Cruz, Bluhm Legal Clinic Center on Wrongful Convictions, http://www.law.northwestern.edu/legalclinic/wrongfulconvictions/exonerations/il/rolandocruz.html (last visited Oct. 19, 2018); see also TRUe StORIES OF FALSE CONFESSIONS (Rob Warden \& Steven Drizin eds., 2009). See generally SCHECK ET AL., supra note 280.

285. Rolando Cruz, supra note 284.

286. Id.

287. Id.

288. Id.

289. Id

290. Id.

291. Id. ("[A]dvanced DNA testing positively excluded Cruz as the source of biological material recovered from the victim and positively linked Dugan to the crime.").

292. Alejandro Hernandez, NAT'L REgisTry EXONERATIONS, https://www.law.umich.edu/special/exoneration/Pages/casedetail.aspx?caseid=3292 (last visited Oct. 4, 2018).

293. Id.

294. Jimerson and another of his friends, Denis Williams, were sentenced to death. 
man and the rape and murder of a woman in Chicago. ${ }^{295}$ Eyewitness testimony (which was recanted but later readopted after the witness was convicted as an accomplice to the crime and for perjury) and imprecise serological testimony led to Jimerson's conviction. ${ }^{296}$ In particular, "State forensic serologist Michael Podlecki testified that Jimerson had Type O blood and was a 'secretor.' The serologist concluded that Jimerson was a possible source of bodily fluid found on a vaginal smear recovered from [one of the victim's] body." 297

Years later, journalism students at Northwestern University began investigating the case and found a tip that police never followed up on. ${ }^{298}$ The tip implicated "three other suspects who would later be recognized as the real perpetrators." ${ }^{299}$ The students sought newly developed DNA evidence, which excluded all of the Ford Heights Four. ${ }^{300}$ The new DNA testing also "inculpated Arthur (Red) Robinson, who confessed to the crime, inculpating three other persons," who were, indeed, the subjects of the then-ignored tip. ${ }^{301}$

\section{H. Frankie Lee Smith (1986)}

Frankie Lee Smith was convicted and sentenced to death for the brutal rape and murder of an eight-year-old girl incident to a home burglary in Florida in $1986 .{ }^{302}$ Based on "shaky eyewitness descriptions from neighbors" and his criminal history, Smith was identified by the victim's mother, who had seen a man "leaving her home through the living room window on the night of the murder." ${ }^{\prime 303}$ Smith died of cancer on death row in $2000 .^{304}$

Eleven months later, new DNA testing exonerated Smith and implicated Eddie Lee Mosley, who was a convicted rapist and murderer. ${ }^{305}$

Another friend, Kenneth Adams, was given 75 years in prison, and Willie Rainge was sentenced to life in prison. Verneal Jimerson, INNOCENCE PROJECT, https://www.innocenceproject.org/cases/verneal-jimerson/ (last visited Sep. 13, 2018).

295. Id.

296. Id.

297. Verneal Jimerson Case Summary, Bluhm Legal Clinic Ctr. on Wrongful CONVICTIONS,

http://www.law.northwestern.edu/legalclinic/wrongfulconvictions/exonerations/documents/i 1JimersonChart.pdf (last visited Sep. 13, 2018).

298. Verneal Jimerson, INNOCENCE PROJECT, supra note 294.

299. Id.

300. $I d$.

301. See Verneal Jimerson Case Summary, supra note 297; Verneal Jimerson, supra note 294. One of the actual perpetrators was already dead, "but the others were convicted of the double murder and acknowledged their involvement in the crime." Verneal Jimerson Case Summary, supra note 297.

302. Frankie Lee Smith, INNOCENCE PROJECT, https://www.innocenceproject.org/cases/frank-lee-smith/ (last visited Sep. 13, 2018).

303. Id. The eyewitness testimony was later recanted. See Requiem for Frank Lee Smith: Eight Things to Know About This Case, PBS: FrontLine, https://www.pbs.org/wgbh/pages/frontline/shows/smith/eight/ (last visited Sep. 13, 2018).

304. Frankie Lee Smith, supra note 302.

305. Id.; see also Jackie Hallifax, DNA Evidence Clears Inmate After His Death, ABCNEws, http://abcnews.go.com/US/story?id=94701\&page=1 (last visited Oct. 19, 2018) 


\section{Ron Williamson (1988)}

Ronald Keith Williamson and an acquaintance were convicted and sentenced to death in 1988 for the sexual assault and murder of a 21-year-old waitress in 1982. ${ }^{306}$ Both men frequented the establishment where the victim worked, and the victim "had previously complained to a friend that [the men] made her nervous." ${ }^{\text {307 }}$ While Williamson was in jail, an inmate told police she heard him talking about the killing. ${ }^{308}$ This testimony, other jailhouse-informant testimony, and an alleged confession by Williamson (in which he recounted a dream he had about killing the victim) were used against him at trial. ${ }^{309}$ Furthermore, forensic investigators found similarities between hairs recovered from the victim and Williamson, and the semen recovered "suggested that the perpetrator(s) were nonsecretors, as [Williamson's acquaintance] and Williamson are." 310

In 1999, both men were exonerated after DNA testing excluded them from the semen left in the victim and "testing proved that none of the many hairs that were labeled 'matches' belonged to them."' ${ }^{111}$ Additionally, the DNA test implicated Glenn Gore, who was the State's main witness at trial. ${ }^{312}$ Not only was Williamson excluded through semen analysis, but an important part of the prosecution's case was forensic testimony that his hair matched those that were found on the victim. Improvements in forensic science that would favor Williamson in this area were discussed earlier in this Article. ${ }^{313}$

\section{J. Robert Miller (1988)}

Robert Lee Miller, Jr. was convicted and sentenced to death for the rape and murder of two elderly women in Oklahoma City in $1988 .{ }^{314}$ Semen, blood, hair, and saliva samples were taken from the crime scenes, which led investigators to believe "the perpetrator was a secretor with type A blood" and that the perpetrator was more likely than not African American. ${ }^{315}$ Miller was "known to police," which resulted in his providing a blood sample and being interrogated. ${ }^{316}$ Miller's test

(reporting prosecutor's conversation with the FBI, in which they stated that Smith "has been excluded, he didn't do it").

306. Ronald Keith Williamson, NAT'L REgISTRY EXONERATIONS, https://www.law.umich.edu/special/exoneration/Pages/casedetail.aspx?caseid=3752 (last visited Oct. 4, 2018).

307. Id.

308. Jim Dwyer, Ronald Williamson, Freed From Death Row, Dies at 51, N.Y. Times (Dec. 9, 2004), http://www.nytimes.com/2004/12/09/us/ronald-williamson-freedfrom-death-row-dies-at-51.html.

309. Ronald Keith Williamson, supra note 306.

310. Id.

311. Id.

312. Ron Williamson, INNOCENCE PROJECT, https://www.innocenceproject.org/cases/ron-williamson/ (last visited Sep. 13, 2018).

313. See supra notes 132-34 and accompanying text.

314. Robert Lee Miller, Jr., NAT'L REgISTRY EXONERATIONS, https://www.law.umich.edu/special/exoneration/Pages/casedetail.aspx?caseid=3473 (last visited Oct. 4, 2018); see also SCHECK ET AL., supra note 280, at 121-37.

315. Robert Lee Miller, Jr., supra note 314.

316. Id. 
showed he was a type-A secretor and, along with the odd responses he gave during his 12-hour interrogation - presumably the result of being "under the influence of marijuana cigarettes dipped in PCP"- was charged and eventually convicted of the crimes. ${ }^{317}$

Miller was granted a new trial, acquitted, and released in 1998 after DNA testing revealed "he could not have been the source" of the semen found at the crime scenes. ${ }^{318}$ Furthermore, more refined analysis showed that the hair comparisons used at trial were "essentially meaningless" and "completely unjustified." 319 The DNA testing also identified the real perpetrator, Ronald Lott, who was "an initial alternate suspect" and "had confessed to two similar crimes... while Miller was incarcerated." $" 320$

\section{K. Ronald Jones (1989)}

Ronald Jones was convicted and sentenced to death for the rape and murder of a 28 -year-old woman in Chicago in $1989 .{ }^{321}$ Jones, an alcoholic, lived in the neighborhood where the crime occurred. ${ }^{322}$ Approximately two months after the murder, Jones was identified by a rape victim as her assailant. ${ }^{323}$ Although he was released on insufficient evidence of the rape, the prosecutor thought he was guilty of both crimes due to the similarities between the rape and the earlier rape-murder. ${ }^{324}$ Jones was arrested later for the rape-murder and confessed to the crime, which detectives claimed was voluntary, but Jones claimed was beaten out of him. ${ }^{325}$ Illinois now requires the videotaping of all custodial police interrogations, ${ }^{326}$ which might have helped Jones demonstrate that this "confession" was a false one.

More importantly, semen was recovered from the scene of the crime, but "the state claimed [it] was too small a quantity to test." 327 Years later, after technology improved, the semen was tested, and it conclusively ruled out Jones as the source of the semen. ${ }^{328}$ 